Western University Scholarship@Western

Business Publications

Business (Richard Ivey School of Business)

$2-2018$

\title{
Risk-Adjusted Inside Debt
}

Frank Li

Ivey Business School, Western University, ourpublic@gmail.com

Shannon Lin

Dalhousie University, ourpublic@gmail.com

Shuna Lin

Fudan University, ourpublic@gmail.com

Alan Tucker

independent, ourpublic@gmail.com

Follow this and additional works at: https://ir.lib.uwo.ca/iveypub

Part of the Finance and Financial Management Commons

\section{Citation of this paper:}

Li, Frank; Lin, Shannon; Lin, Shuna; and Tucker, Alan, "Risk-Adjusted Inside Debt" (2018). Business Publications. 18. https://ir.lib.uwo.ca/iveypub/18 


\title{
Risk-Adjusted Inside Debt
}

\author{
Frank $\mathrm{Li}^{1}$ \\ University of Western Ontario \\ Shannon $\operatorname{Lin}^{2}$ \\ Dalhousie University \\ Shuna Sun $^{3}$ \\ Fudan University \\ Alan Tucker ${ }^{4}$
}

Li, F., Lin, S., Sun, S., and Tucker, A., 2018. Risk-Adjusted Inside Debt. Global Finance Journal 35: $12-42$.

\begin{abstract}
Compensation theory holds that executive aggression is related to both the level and riskiness of "inside debt" - promises from firms to pay their executives fixed sums of cash in the future, including pensions and deferred compensation. However, previous researchers have only examined the level of inside debt. We provide an inside debt metric that is conceptually superior to previously used metrics, as it incorporates the riskiness of inside debt. For the entire sample, our metric offers modest improvement in fit over past metrics, where the dependent variable is future equity return volatility. Furthermore, the relation between future volatility and our riskadjusted inside debt metric is more prominent for non-investment grade firms, firms experiencing credit rating downgrades, and firms with high credit risk.
\end{abstract}

Keywords: Corporate conservatism; inside debt; executive compensation.

Acknowledgement: The authors thank Sean Cleary, Queen's University, Canada, and Feng Chen, University of Missouri, for helpful comments.

\footnotetext{
${ }^{1}$ Ivey Business School, University of Western Ontario, 1255 Western Road - Room 3322, London, Ontario, Canada, N6G 0N1. Email: fli@ivey.ca.

${ }^{2}$ Rowe School of Business, Dalhousie University, Room 4090, 6100 University Avenue, Halifax, Nova Scotia, Canada B3H 4R2. Email: Shannon.Lin@Dal.ca.

${ }^{3}$ Corresponding author. School of Business, Fudan University, $7^{\text {th }}$ Floor, Li Dasan Building, 670 Guoshun Road, Yangpu District, Shanghai, China. Email: shunasun12@fudan.edu.cn.

${ }^{4}$ Private sector.
} 


\section{Risk-Adjusted Inside Debt}

\section{Introduction}

Top executives work, in part, in exchange for promises from their firms to pay them fixed sums of cash in the future, including pensions and deferred compensation, known as "inside debt" in the language of Jensen and Meckling (1976). As first documented by Sundaram and Yermack (2007), managers become more conservative in their investment, financing, and other corporate decisions as their compensation mix tilts from equity-based to debt-based, which is typical as they age. Specifically, Sundaram and Yermack (2007) find that as a CEO's pension value increases relative to his equity value, risk-taking as measured by distance-to-default declines. They note that very large holdings of inside debt may even lead to an overly conservative management style. ${ }^{5}$

Subsequent studies provide additional support for a direct relation between the level of executive inside debt and corporate conservatism. In a widely cited study, Cassell, Huang, Sanchez, and Stuart (2012) indicate that CEO inside debt holdings are generally unsecured and unfunded liabilities of the firm and therefore expose the CEO to default risk similar to that faced by outside creditors. They find a negative association between the level of CEO inside debt holdings and the volatility of future firm stock returns, research and development expenditures (R\&D), and financial leverage, and a positive association between the level of CEO inside debt holdings and the extent of firm

\footnotetext{
${ }^{5}$ Distance-to-default is a common metric used in fixed income analytics to assess the overall riskiness of a firm. Loosely speaking, it is the number of standard deviation decreases in firm value that will cause the firm to default on its debt.
} 
diversification and asset liquidity. Other notable studies involving various aspects of corporate conservatism, executive compensation, and the level of inside debt include Edmans and Liu (2011), Wei and Yermack (2011), Anantharaman, Fang, and Gong (2013), Eisdorfer, Giaccotto, and White (2013), Kabir, Li, and Yulia (2013), Liu, Mauer, and Zhang (2014), Chi, Huang, and Sanchez (2014), Abhishek, Armitage, and Hagendorff (2014), Choy, Lin, and Officer (2014), and Kubick, Lockhart, and Robinson (2014), among many others. ${ }^{6}$

The aforementioned studies hypothesize and test that corporate conservatism (aggression) increases (decreases) as the level of inside debt rises. However, this is not precisely what executive compensation theory states. The theory also holds that conservatism (aggression) increases (decreases) as the riskiness of inside debt rises. For example, if a CEO has high absolute inside debt, he nevertheless may be aggressive if the expected probability of default (expected recovery rate) of his inside debt is zero (100 percent). For another example, if a CEO has low inside debt, he may nevertheless be relatively conservative if the expected probability of default (expected recovery rate) of his inside debt is high (low). Previous studies fail to account for the risk element of inside debt theory, and their empirical hypothesis of a direct relation between conservatism and the level of inside debt is somewhat incomplete. A more properly stated hypothesis of Jensen and Meckling's theory of inside debt incentives would be that there exists a direct relation between conservatism and the credit risk-adjusted level

\footnotetext{
${ }^{6}$ There is also a large body of literature regarding corporate conservatism and managerial equity incentives, cf. Coles, Naveen, and Naveen (2006).
} 
of inside debt. ${ }^{7}$ Given the sophistication and resources of CEOs, it is reasonable to assume that they understand the difference - in terms of their incentives - between the level of their inside debt and the credit risk-adjusted level of their inside debt. Previous researchers have pooled risky and less-risky inside debt, resulting in outcomes that are somewhat difficult to interpret economically. The compensation policies based on the outcomes may become suboptimal. By not differentiating between the qualities of inside debt, past researchers have not fully explored the empirical relation between conservatism and inside debt. ${ }^{8}$

Our examination of the credit risk of inside debt reveals that there can be important differences between raw and credit risk-adjusted inside debt levels, especially for very credit risky firms. Supposing that two CEOs have the same level of inside debt, the CEO in the more credit risky firm will be more conservative. This leads us to hypothesize that the relation between CEO conservatism and CEO inside debt may be stronger once the credit risk of inside debt is accommodated, particularly for high-risk

\footnotetext{
${ }^{7}$ The level of inside debt per se is merely its promised value. The credit risk-adjusted level of inside debt is its expected value, i.e., the promised value less anticipated loss due to the firm's failure to pay. Theory holds that the executive will make decisions based on the expected value of his inside debt holding, and not its promised value.

${ }^{8}$ For example, the popular measure of inside debt, "k", constructed in Cassell et al. (2012) and other studies, does not adjust for the expected probability of inside debt default or the expected recovery rate on inside debt in the event of default. The metric $\mathrm{k}$ is a special case/nested version of our metric; $\mathrm{k}$ is obtained from our metric (called $\mathrm{k}^{*}$ ) after setting the expected default probability on inside debt equal to zero or the expected recovery rate (in the event of default) equal to 100 percent. Put another way, the popular $\mathrm{k}$ metric uses the promised value of inside debt, while our adjusted k metric uses the expected value of inside debt. See sections 2 and 3.1 below. There is a sort of irony to using the promised value of inside debt (in prior studies); while researchers recognize that the theory states that executives holding inside debt are concerned about its credit risk, by using promised value the researchers nevertheless implicitly treat the inside debt as if it were default risk-free.
} 
firms. For instance, in our data, Cardinal Health Care (R. Kerry Clark, CEO) had in 2009 a higher raw-k metric, which is the popular measure of inside debt level first constructed in Cassell et al. (2012), than Corning (Wendell Weeks, CEO). According to previous empirical studies, this would imply that the CEO of Cardinal (Corning) should be relatively less (more) aggressive. However, for the same year the credit risk-adjusted k metric of Cardinal was lower than that of Corning, implying that the CEO of Cardinal (Corning) should, according to the theory, be in fact relatively more (less) aggressive. The likely reason for this ordinal change in predicted aggression is reflected in the firms' differential credit risk. As indicated by their 2009 credit ratings, Cardinal's debt was investment grade while Corning's was non-investment grade (junk), indicating that Corning's CEO should be more concerned about the prospect of not collecting his inside debt than Cardinal's CEO. ${ }^{9,10}$

Our study makes three contributions to the literature relating to executive aggression and inside debt. First, to the best of our knowledge, our study is the first to provide a metric that reflects a credit risk-adjusted level of inside debt, and is therefore conceptually superior to previously used metrics. Second, we demonstrate empirically that our metric is a more powerful determinant of corporate conservatism, as captured by future firm stock return volatility, relative to raw-k. While the improvement in fit offered

\footnotetext{
${ }^{9}$ In Cassell et al.'s k metric, a lower level of k implies that the CEO should be more aggressive. With our risk-adjusted $\mathrm{k}$ metric, a lower level of $\mathrm{k}^{*}$ also implies that the CEO should be more aggressive.

${ }^{10}$ In general, the difference between $\mathrm{k}$ and $\mathrm{k}^{*}$ widens as the credit quality of the firm diminishes, because the likelihood that the CEO collects the promised value of his inside debt falls. Empirical results confirm this difference; see section 4.1 and Figure 1 below.
} 
by our metric is modest for the overall sample, it is more pronounced for non-investment grade firms, firms experiencing credit downgrades, and firms with high credit risk. Third, in a related test designed to control for endogeneity, we show that the relation between inside debt and executive conservatism heightens during the 2007-08 credit crisis.

When conducting our tests, we first replicate those conducted by Cassell et al. (2012) where return volatility is the dependent variable. ${ }^{11}$ We use their k metric and find qualitatively and quantitatively similar results to those reported by Cassell et al. (2012). We then repeat the tests while substituting our adjusted $\mathrm{k}$ metric. We detail the construction of our metric in Section 3.1. ${ }^{12}$ Our metric accounts for both the expected cumulative default probability and expected recovery rate of inside debt (unsecured, with appropriate maturity), initially using data provided by Moody’s Investor Services. Thus, our paper represents a blending of the literatures on executive compensation and credit risk measurement. For the overall sample of firms, the coefficient of our $\mathrm{k}^{*}$ metric is greater (in absolute value) and has a larger t-value than those, respectively, of the coefficient of the raw-k metric in Cassell et al. (2012). ${ }^{13}$ Therefore, our results indicate

\footnotetext{
${ }^{11}$ We choose future stock return volatility as the managerial choice variable because it is a broad measure of risk, highly correlated with credit spreads, and therefore closely related to distance-to-default.

${ }^{12}$ We use the expected value of the inside debt by incorporating the expected default probability and the expected recovery rate of executives' inside debt in the event of default, rather than its promised raw value. The executives should be concerned about the expected value of their inside debt instead of the raw value, per the (correct) theory on inside debt. An analogy is the valuation of executive options with probability (or riskiness) included (i.e., $\mathrm{N}($ ) in the Black-Scholes model).

${ }^{13}$ Note that the raw-k metric of Cassell et al. is already significant at the $1 \%$ critical level. It is difficult to improve at such a high level (at least in empirical finance). Therefore the fact that $\mathrm{k}^{*}$ shows any improvement over raw-k is rather remarkable, statistically speaking. We return to this matter in Section 4.
} 
that the relation between CEO conservatism and the level of CEO risk-adjusted inside debt is stronger than the relation between CEO conservatism and the level of CEO raw inside debt. Moreover, the improvement in fit offered by our metric is more pronounced for non-investment grade firms, firms that have experienced a ratings downgrade, and firms with high credit risk. ${ }^{14}$ That is, the gap between the significance of $\mathrm{k}^{*}$ and that of $\mathrm{k}$ seems to widen both economically and statistically for these risky firms.

When repeating the tests of Cassell et al. (2012), we are careful to use similar methods including the choice of documented control variables and, for two-stage tests designed to address endogeneity, the choice of instrument variables. For firms with little debt, our metric $\mathrm{k}^{*}$ - like the unadjusted $\mathrm{k}$ metric - can be artificially high, suggesting that the executive should be quite conservative. ${ }^{15}$ Following Cassell et al. (2012, footnote 19, page 596), we keep sample firms with raw-k values greater than or equal to 10, though eliminating these firms does not impact our results. ${ }^{16}$ Also, we investigate the

\footnotetext{
${ }^{14}$ One may initially wonder why we adjust the executive's inside debt for credit risk but do not adjust the firm's (outside) debt for credit risk. The reason is obvious, however; from the executive's perspective, the inside debt is an asset and therefore subject to default risk, while from the firm's perspective both the inside and outside debt are liabilities. Also, like those cited previously, our study fails to control for the possibility that CEOs are hedging their inside debt risk, presumably via derivative securities, which would have the effect of bifurcating executive compensation design and executive risk taking. However, if CEOs are hedging their credit risk exposure to their firms, such hedging would only serve to bias results toward a finding of no relation between risk-adjusted inside debt and corporate conservatism.

${ }^{15}$ To understand this result, note that the raw-k metric is given by [VED/VEE]/[VFD/VFE], where VED is the promised value (i.e., level) of the executive's inside debt, VEE is his equity value, VFD is the (book) value of the firm's (outside) debt, and VFE is the equity value of the firm. For low debt firms (low VFD) $\mathrm{k}$ can be very large. Note that the raw-k metric is a measure of relative CEO leverage, i.e., raw-k is the ratio of CEO debt-to-equity to firm debt-to-equity.

${ }^{16}$ Another reason why raw-k values can be unusually high is that firms may be relying less on equity instruments to compensate their CEOs, i.e., VEE is unusually low.
} 
prospect that a change in CEO could be driving the results, but find that results remain intact after controlling for this possibility.

Another concern in our empirical setting is that stock volatility and credit risk (captured by our adjusted k) should be highly positively correlated (Merton, 1974), as both are determined by firm fundamental risk. However, this endogeneity problem actually works against us finding the documented negative relation between our inside debt measure and future stock volatility. Furthermore, we use a powerful natural experiment to address endogeneity. We find that, during the credit crisis of 2007 and 2008, the relation between CEO conservatism (aggression) and both raw-k and our measure of risk-adjusted inside debt $\left(\mathrm{k}^{*}\right)$ heightens (wanes) when compared to the relation during the non-credit crisis period. The examination of the credit crisis period presents a unique experiment that addresses endogeneity concerns because, absent some other cogent reasons for CEOs to become more conservative, the finding indicates that corporate planning is sensitive to a CEO's personal credit risk exposure. Like more traditional creditors, CEOs appear to reduce risk when general credit conditions deteriorate.

Finally, for robustness we use alternative methods of adjusting inside debt levels for the credit riskiness of the debt. We use ratings data from two major rating agencies. In addition, we use expected default probabilities and expected recovery rates implied from credit default swaps for a small subsample of firms. Regardless of which rating agency we use, or if we use credit default swap spreads, we find that the relation 
between future firm equity return volatility and our credit risk-adjusted $\mathrm{k}$ metric is stronger than the relation for raw-k. ${ }^{17}$

Section 2 provides our motivation and hypothesis development. Section 3 explains our main research design. Section 4 discusses the sample selection process and major empirical results. Section 5 presents the credit crisis test, the new CEO test, and other robustness tests. Section 6 concludes.

\section{Motivation and Hypothesis Development}

Executive compensation contracts are structured to align the interests of managers with those of owners (Berle and Means, 1932; Jensen and Meckling, 1976; Bebchuk and Jolls, 1999). While the literature on the incentive effects of compensation packages mainly focuses on equity-based compensation (Murphy, 1985; Lambert and Larcker, 1987; Morck, Schleifer, and Vishny, 1988; Coles et al., 2006), a newer and growing body of studies has focused on debt-based compensation in light of the recognition that inside debt may be prevalent and substantial. Over $80 \%$ of CEOs hold some form of inside debt which on average amounts to $\$ 10$ million (Wei and Yermack, 2011). Consistent with such large holdings, the literature demonstrates directly or indirectly that executives with greater levels of inside debt protect the value of their

\footnotetext{
${ }^{17}$ Given the efficiency of the credit markets, and the rarity of "split ratings", it is not surprising that results are similar when adjusting inside debt using different ratings firms as well as credit default swap spreads. We find that the values of the product [DP $\mathrm{x}(1-\mathrm{RR})]$ obtained from different rating agencies, as well as from swap spreads, are all highly correlated. A split rating occurs when two different rating agencies provide different credit ratings to the same firm/instrument.
} 
holdings by practicing more conservatism. For example, Sundaram and Yermack (2007) show that CEO inside debt is positively related to distance to default. Also, inside debt has been linked to both the cost of debt and the use of debt covenants (Anantharaman, Fang, and Gong, 2013; Wang, Xie, and Xin, 2010), as well as accounting conservatism (Chen, Dou, and Wang, 2010). In addition, Cassell et al. (2012) demonstrate that CEOs with large inside debt protect their holdings by implementing less risky investment and financial policies.

The promised value of inside debt represents its default-free value. According to theory, however, the value of CEO inside debt holdings is sensitive to both the probability of bankruptcy and the liquidation value of the firm in the event of bankruptcy or reorganization (Jensen and Meckling, 1976). Thus, by pooling risky and less-risky inside debt without differentiating between the qualities of inside debt, past empirical researchers have not fully explored the empirical relation between executive conservatism and inside debt, especially for high-risk firms. By accommodating the credit risk of inside debt, this study provides, for the first time, an inside debt metric that is conceptually superior to previously used metrics.

More specifically, the popular measure of inside debt $(\mathrm{k})$ constructed in the current literature (e.g., Wei and Yermack, 2011; Cassell et al., 2012; Anantharaman, Fang, and Gong, 2013) does not adjust for the expected probability of inside debt default or the expected recovery rate on inside debt in the event of default. The metric $\mathrm{k}$ is a nested version of our metric; $\mathrm{k}$ is obtained from our metric, $\mathrm{k}^{*}$, after setting the expected 
default probability on inside debt equal to zero or the expected recovery rate (in the event of default) equal to 100 percent. In other words, the popular k metric uses the promised value of the inside debt payoff, while our adjusted $\mathrm{k}$ metric uses its expected value.

We build on the theoretical arguments of Jensen and Meckling (1976) and Edmans and Liu (2011), who posit that inside debt holdings are likely to elicit increased conservatism. More specifically, we predict that there is lower future firm equity return volatility associated with more credit risk-adjusted inside debt. This relation should be more prominent than was previously found based on the traditionally used raw-k metric. Thus our main hypothesis is:

H1: There is a more powerful negative association between CEO credit risk-adjusted inside debt holdings and the volatility of future firm stock returns than the previously documented relation between CEO raw inside debt holdings and the volatility of future firm stock returns. Furthermore, this more powerful negative association is especially apparent for very credit risky firms.

To test this hypothesis, we first investigate all sample firms using $\mathrm{k}$ and $\mathrm{k}^{*}$, and find that $\mathrm{k}^{*}$ exhibits a slightly better fit to the data. We further focus on more credit risky firms, and find that the improvement in fit is enhanced for subsamples consisting of noninvestment grade firms, firms that experienced a ratings downgrade, and credit risky firms.

3. Main Research Design 
In this section, we provide a broad overview of our testing methods, first starting with an introduction of our credit risk-adjusted metric $\mathrm{k}^{*}$ and the intuition behind its various inputs. Please see Appendix A for details regarding the calculation of $\mathrm{k}^{*}$, which is our main independent variable. We further discuss our regression models as well as the measurement of our main dependent variables in this section.

\subsection{CREDIT RISK-ADJUSTED METRIC}

Our metric, $\mathrm{k}^{*}$, which accommodates the credit riskiness of inside debt, is given by:

$$
\mathrm{k}^{*}=\{[(\mathrm{VED}-(\mathrm{VED})(\mathrm{DP})(1-\mathrm{RR})) / \mathrm{VEE}] /[\mathrm{VFD} / \mathrm{VFE}]\}
$$

where VED is the promised value (i.e., level) of the executive's inside debt; DP is the expected cumulative default probability on the inside debt; RR is the expected recovery rate on the inside debt in the event of its default; VEE is the executive's equity value; VFD is the book value of the firm's outside debt; and VFE is the equity value of the firm. From the executive's perspective, inside debt is one element of the firm's unsecured outside debt. Thus, DP is best represented by the expected cumulative probability of default of the firm's unsecured outside debt, with appropriate maturity.

Note that the raw-k metric is given by [VED/VEE]/[VFD/VFE], without considering DP and RR. To obtain $\mathrm{k}^{*}$, we substitute the expression \{VED $[(\mathrm{VED})(\mathrm{DP})(1-\mathrm{RR})]\}$ for VED in the original $\mathrm{k}$. Thus we use the expected value of the inside debt (the term in braces), rather than its promised value (merely VED). The term 
$[(\mathrm{VED})(\mathrm{DP})(1-\mathrm{RR})]$ is, of course, the executive's expected loss on his inside debt. With a greater DP or lower RR, the expected loss is greater, the expected value of inside debt is lower, the $\mathrm{k}^{*}$ is lower, and therefore the executive will be more conservative, per the (correct) theory on inside debt.

There are several features of $\mathrm{k}^{*}$. First, for low-debt firms (low VFD), $\mathrm{k}^{*}$ (like k) can be very large. Second, for firms that compensate their executives with little equity (low VEE), k* (like k) can be very large. Like Cassell et al. (2012) we do not restrict k*, and the elimination of firms with $\mathrm{k}^{*}$ greater than 10 does not affect our results. Third, like $\mathrm{k}, \mathrm{k}^{*}$ is a measure of relative $\mathrm{CEO}$ leverage, i.e., $\mathrm{k}^{*}$ is a ratio of CEO debt-to-equity to firm debt-to-equity. As such, a lower value of $\mathrm{k}^{*}$ suggests greater CEO aggression, and thus more future firm stock return volatility. Fourth, whereas VED is the promised value of the executive's inside debt, the product (VED - (VED)(DP)(1 - RR)) is the expected value of the inside debt. Fifth and foremost, $\mathrm{k}$ is obtained from $\mathrm{k}^{*}$ by either setting DP equal to 0 (no default) or RR equal to 1 (full recovery in the event of a default). In other words, $\mathrm{k}$ is a nested version of $\mathrm{k}^{*}$, the former obtained by erroneously assuming that inside debt is default-free.

When computing $\mathrm{k}^{*}$ we use the exact same procedures as Cassell et al. (2012) to obtain VED, VEE, VFD, and VFE. As such, we obtain similar raw-k metrics to those reported by Cassell et al. (2012). As described in detail in section 4.1., to obtain DP and RR we initially use ratings data and their corresponding historical default probabilities and recovery rates provided by Moody's Investor Services. We use data corresponding 
to the firm's unsecured outside debt whose maturity most closely matches the expected maturity of the CEO's inside debt: the latter is defined as the difference between retirement age and current CEO age. For robustness, we also use ratings data provided by Standard \& Poor's, as well as credit default spread data, the latter of which is available for a subsample of firms.

\subsection{MODELING FUTURE FIRM STOCK RETURN VOLATILITY AND k*}

Cassell et al. (2012) document a negative association between CEO inside debt holdings and the volatility of future firm stock returns. The starting point of our investigation is to replicate their main finding and then introduce our measure $\mathrm{k}^{*}$. We model the relationship between firm stock volatility and CEO inside debt holdings while closely following Cassell et al. (2012), using the following regression specifications:

Volatility of future firm stock returns

$$
\begin{aligned}
& =\alpha_{0}+\beta_{0} * \text { CEO to firm debt/equity ratio }+\sum_{i=1}^{n} \beta_{0} * \text { Controls } \\
& +\beta_{n+1} * \text { Industry fixed effects }+\beta_{n+2} * \text { Year fixed effects } \\
& +\varepsilon(O L S)
\end{aligned}
$$

Volatility of future firm stock returns

$$
\begin{aligned}
& =\alpha_{0}+\sum_{i=1}^{k} \beta_{i} * \text { Instruments }_{i}+\sum_{j=k+1}^{k+n} \beta_{j} * \text { Controls }_{j}+\beta_{k+n+1} \\
& * \text { Industry fixed effects }+\beta_{k+n+2} * \text { Year fixed effects } \\
& +\varepsilon(2 S L S)
\end{aligned}
$$


Where:

Volatility of future firm stock returns is one of two variables: Log of total risk or Log of idiosyncratic risk. Each of these is measured over two windows: $t+1$ and $t+1$ to $\mathrm{t}+3$ (see section 3.2.1.1);

CEO to firm debt/equity ratio is one of two variables: Log of CEO to firm debt/equity ratio or $\mathrm{k}$, Log of adjusted CEO to firm debt/equity ratio or $\mathrm{k}^{*}$ (see section 3.2.1.2.);

Controls is a vector of control variables (see Appendix B);

Instruments is a vector of instrumental variables (see section 4.3.);

Industry fixed effects is a vector of dummy variables for each two-digit SIC code represented in the sample; and

Year fixed effects is a vector of dummy variables for each year represented in the sample.

First we conduct an OLS analysis using equation (2). We then proceed to a 2SLS analysis in which we first regress $\mathrm{k}$ and $\mathrm{k}^{*}$ on our instruments using equation (3), and then use the predicted values from the first-stage regression results as explanatory variables in equation (2) as the second stage.

\subsubsection{Variable Measurement}

3.2.1.1. Measurement of volatility of future firm stock returns

Following the prior literature (Cassell et al., 2012; Xu and Malkiel, 2003), we adopt two measures of volatility of future firm performance. The first is total risk as measured by the variance of daily firm stock returns in fiscal year $t+1$ (Cassell et al., 2012; Coles, Daniel, and Naveen, 2006). The second is idiosyncratic risk estimated as 
the variance of daily residual returns in fiscal year $t+1$. We use daily firm returns data 36 months prior to the beginning of fiscal year $\mathrm{t}+1$ to estimate the market model $(\mathrm{Xu}$ and Malkiel, 2003). We construct expected daily stock returns in fiscal year $t+1$. By subtracting the expected daily returns from the realized returns, we obtain the daily residual returns. Idiosyncratic risk is then estimated as the variance of daily residual returns in fiscal year $t+1$. We take the natural logarithm of both measures to mitigate the concern that skewness in the distribution of these measures may affect our inferences (Core and Guay, 1999; Goyal and Santa Clara, 2003; Xu and Malkiel, 2003). To mitigate concerns that our time window is not long enough to capture the implications of firm policy choices on the volatility of future firm performance, as in Cassell et al. (2012), we also construct total risk and idiosyncratic risk over the window $\mathrm{t}+1$ through $\mathrm{t}+3$ as alternative measures. After requiring that firms have complete data to obtain the volatility of future firm stock returns from $t+1$ through $t+3$, our initial sample size is 3,899 firm-year observations covering fiscal years 2006 to $2010 .{ }^{18}$

\subsubsection{Measurement of CEO inside debt holdings}

The literature to date has measured CEO inside debt holdings as $\mathrm{k}$ or the CEO to firm debt/equity ratio scaled by the firm's debt-to-equity ratio (Cassell et al., 2012; Sundaram and Yermack, 2007; Edmans and Liu, 2011). Formulaically,

$$
k=\left(\frac{V E D}{V E E}\right) /\left(\frac{V F D}{V F E}\right)
$$

\footnotetext{
${ }^{18}$ As discussed momentarily, subsequent data requirements will further reduce our final testing sample to 1,984 firm year observations.
} 
We offer an improved measure of inside debt that is grounded in modern credit risk measurement. We adjust the original $\mathrm{k}$ measure to arrive at our $\mathrm{k}^{*}$ metric - the adjusted CEO to firm debt/equity ratio. In particular, we adjust the "raw" inside debt for the firm's probability of default and the executive's expected recovery rate. We assume that the amount of inside debt owed to the CEO is VED. Denoting the expected default probability and the expected recovery rate of executives' inside debt as DP and RR respectively for the appropriate maturity, the expected loss (EL, i.e., the "true" credit risk) to the $\mathrm{CEO}$ is: $\mathrm{EL}=\mathrm{VED} * \mathrm{DP} *(1-\mathrm{RR})$.

Our inside debt measure adjusted by creditability is defined as:

$$
k^{*}=\left(\frac{V E D-E L}{V E E}\right) /\left(\frac{V F D}{V F E}\right)
$$

Therefore,

$$
\begin{gathered}
k^{*}=\left(\frac{V E D-E L}{V E E}\right) /\left(\frac{V F D}{V F E}\right)=\left[\frac{V E D-V E D * D P *(1-R R)}{V E E}\right] /\left(\frac{V F D}{V F E}\right) \\
=[1-D P *(1-R R)] *\left(\frac{V E D}{V E E}\right) /\left(\frac{V F D}{V F E}\right)
\end{gathered}
$$

Comparing our $\mathrm{k}^{*}$ to the original $\mathrm{k}$ in the literature (e.g., Jensen and Meckling, 1976; Sundaram and Yermack, 2007; Edmans and Liu, 2011; Cassell et al., 2012), it is apparent that the raw-k measure is a special case of $\mathrm{k}^{*}$ :

$$
k^{*}=[1-D P *(1-R R)] * k \stackrel{D P=0, R R=1}{\Longrightarrow} k^{*}=k
$$

Aside from inside debt holdings, VED, there are three additional inputs in equation (5): DP and RR of inside debt, and the Maturity of DP and RR. Because these inputs are not directly observable, we need proxies to conduct our empirical tests. Our proxy for Maturity is the adjusted CEO's expected decision horizon with the firm. As for 
the CEO decision horizon (DH), we follow Antia, Pantzalis, and Park (2010) to further adjust the CEO's expected DH for industry median age and industry median tenure. We believe this is the most appropriate maturity that balances the CEO's expected decision horizon and the data limitation imposed by the firm's bond issuances. ${ }^{19}$ To estimate DP and RR, we use Moody's updated statistics on the cumulative global default rates both by letter rating and by alphanumeric rating since 1920 in their annual default study. Refer to Appendix A for details of the calculation of our adjusted inside debt measure. To calculate $\mathrm{k}^{*}$, there must be at least one bond whose maturity can capture the CEO's expected decision horizon, so that we are able to obtain the firm's rating, cumulative default rate, and expected recovery rate. However, for some firms no such bond exists. For these cases, we estimate a company's debt rating, cumulative default rate, and expected recovery rate based upon comparable companies. ${ }^{20}$

\section{Data and Discussion of Major Empirical Results}

In this section, we provide details on how our sample was selected, and discuss basic summary statistics for variables found in this study. We illustrate that our main

\footnotetext{
${ }^{19}$ In practice it is not always possible to identify a corporate bond whose time-to-maturity exactly captures the maturity of the CEO's inside debt. Moreover, the cumulative default rates and expected recovery rates reported by Moody's only cover years 1 through 20. The term "most appropriate maturity" is defined as the most reasonable proxy for the maturity of CEO's inside debt on the basis of balancing the extant firm's bonds, the CEO's expected decision horizon and the period coverage of Moody's report on default rates and recovery rates. See Appendix A for details of this proxy derivation.

${ }^{20}$ Following Sundaram and Yermack (2007), for firms without a bond rating, we estimate a company's debt rating based on comparable companies. We select comparable companies for a firm based on twodigit SIC code and firm size, and use the average rating of its comparable companies as the proxy.
} 
independent variable $\mathrm{k}^{*}$ can differ substantially from $\mathrm{k}$ when credit conditions deteriorate. We show results for OLS and 2SLS regressions, and split our sample based on different measures of credit risk.

\subsection{SAMPLE SELECTION PROCESS}

We attempt to cover all observations reported under the FAS $123 \mathrm{R}$ issued by the FASB in 2004 (OLD_DATAFMT_FLAG=0) during fiscal years 2006 to 2014. Prior to 2006, reporting rules did not require firms to disclose their CEOs' inside debt positions. Because our data was pulled as of August 2014 and we have few observations for fiscal 2014 in Execucomp, we narrow the range to fiscal 2006 to 2013. Since the Merged CRSP/Compustat Database ends in fiscal 2012, we convert the permnos through cusips into GVKEY for the daily 2013 prices to merge CRSP and Compustat for fiscal 2013 and use the extant data in Merged CRSP/Compustat for fiscal years 2006-2012. As mentioned in the last section, our measurements of the volatility of future firm stock returns are variances of daily firm stock returns in year $t+1$ through $t+3$. Our final sample covers all observations from fiscal 2006 to 2010 with complete data on compensation in Execucomp to compute inside debt measures, as well as on stock prices/financial statements in CRSP/Compustat to estimate the dependent variables and all the control variables. The above requirements leave us with 1,984 firm-year observations.

Panel A of Table 1 displays the summary statistics of $\mathrm{k}$ and $\mathrm{k}^{*}$, including key components of CEO compensation that are used as inputs to calculate $\mathrm{k}$ and $\mathrm{k}^{*}$. The 
table also contains our dependent variables and additional regression control variables for fiscal years 2006-2010. Note that $\mathrm{k}$ and $\mathrm{k}^{*}$ have high standard deviations and that there are some unusually high $\mathrm{k}$ and $\mathrm{k}^{*}$ values in the sample. This finding is not surprising because, per Cassell et al. (2012), some firms have unusually small debt-toequity ratios and rely less on equity instruments to compensate their CEOs, resulting in higher CEO-specific debt-to-equity ratios.

\section{[Insert Table 1]}

In Figure 1, we show that the spread between $\mathrm{k}$ and $\mathrm{k}^{*}$ widens as we move from Aaa down to Ccc. We also illustrate that the mean values of $\mathrm{k}$ and $\mathrm{k}^{*}$ begin to increase after the 2008 credit crisis, which may indicate that inside debt holdings are becoming a more important component of CEO compensation.

\section{[Insert Figure 1]}

\subsection{RESULTS FOR OLS ESTIMATION}

We replicate the main tests conducted by Cassell et al. (2012) where the independent variable is the original raw-k metric. We are careful to use similar methods, including the choice of documented control variables. In Table 2 we see results that are very similar to those of Cassell et al. (2012) for our sample from 2006-2010. Note that our sample period is longer than Cassell et al.'s, and this is likely the reason that our results vary slightly. In Panel A, we have the log of idiosyncratic risk (Columns 1-4) and the $\log$ of total risk for $\mathrm{t}+1$ (Columns 5-8) as dependent variables, and in Panel $\mathrm{B}$ we 
have the log of idiosyncratic risk (Columns 1-4) and log of total risk for $\mathrm{t}+3$ (Columns 58) as dependent variables. The four explanatory variables ${ }^{21}$ are of largely negative significance in explaining the dependent variables, showing that CEOs with more inside debt implement more conservative corporate policies.

\section{[Insert Table 2]}

We next repeat the same analysis and instead use $\mathrm{k}^{*}$ as the main explanatory variable. Recall that the calculation of $\mathrm{k}^{*}$ requires several additional inputs, the overall effect of which is to reduce the sample size to 1,984 firm-year observations. In Table 3 we compare $\mathrm{k}$ and $\mathrm{k}^{*}$ side by side, based on the same sample, and in each case the $\mathrm{k}^{*}$ measure has a larger coefficient (in absolute value) and a larger t-stat than the original $\mathrm{k}^{22}$ For example, in Columns (1-2) the coefficient on $\mathrm{k}^{*}$ is -0.0467 with t-stat of -3.74 , which are both larger than k's coefficient of -0.0460 and its t-stat of -3.68 . This pattern of $\mathrm{k}^{*}$ 's superior ability to predict the dependent variables can be seen throughout Table 3.

\section{[Insert Table 3]}

While it appears at first glance that the improved fit offered by $\mathrm{k}^{*}$ over $\mathrm{k}$ is nominal for the overall sample, the reader should keep in mind that the coefficient on $\mathrm{k}$ is already significant at the $1 \%$ critical level. In general, it is, empirically speaking,

\footnotetext{
${ }^{21}{ }^{21}$ For detailed definitions of the four k measures, please refer to Cassell et al. (2011). For simplicity, we use, throughout the paper, the $\mathrm{k}$ measure, the most used measure in Cassell et al. (2011). However the other three alternative measures generate similar results for all our tests.

${ }^{22}$ For firms with little debt, the $\mathrm{k}$ or $\mathrm{k}^{*}$ metrics can be artificially high, suggesting that the executive should be quite conservative. However, consistent with Cassell et al. (2012, footnote 19, page 596), we obtain similar results if we eliminate sample firms with raw-k values greater than or equal to 10 .
} 
difficult to improve upon an explanatory variable that is significant at such a high level. The fact that $\mathrm{k}^{*}$ offers any improvement in fit is an empirical testament to its prowess. The obvious conceptual superiority of $\mathrm{k}^{*}$ is, in general, supported empirically by the results in Table 3. Overall, the results presented in Table 3 support our main hypothesis, H1.

\subsection{A "HORSE RACE"}

In order to directly compare the explanatory power of $\mathrm{k}$ and $\mathrm{k}^{*}$, we conduct a "horse race" by putting both measures in the same regressions. In Table 4 Panel A, the OLS results show that the coefficients of $\mathrm{k}$ become positive and insignificant, while the coefficients of $\mathrm{k}^{*}$ remain negative, which is consistent with the theory, but insignificant. The extremely high VIF (Variance inflation factors) of $\mathrm{k}$ and $\mathrm{k}^{*}$, much higher than the rule-of-thumb value 10 (Belsley, 1991), indicates that the co-existence of $\mathrm{k}$ and $\mathrm{k}^{*}$ leads to the multicollinearity problem, which increases the variance of the estimators and makes the estimated parameters unstable and insignificant (Kutner et al., 2004).

To address the multicollinearity problem, we follow Hoerl and Kennard (1970a, b) and Vinod (1978) by using ridge regression. Specifically, we estimate parameters via a "shrinkage" method that incorporates a small amount of bias into the estimating equation, thereby substantially reducing the sampling variance of the estimators in the presence of correlated data. See Appendix C for detailed discussion of ridge regression. The results in Table 4 Panel B show that $\mathrm{k}^{*}$ outperforms $\mathrm{k}$ consistently, both in statistical 
significance and economical significance. In particular, when included in the same regressions, $\mathrm{k}$ becomes insignificant while $\mathrm{k}^{*}$ remains highly significant. Our riskadjusted measure of inside debt seems, therefore, more relevant in determining firm risk.

[Insert Table 4]

\subsection{RESULTS FOR TWO-STAGE LEAST SQUARES ESTIMATION}

We alternatively use two-stage tests designed to address endogeneity and utilize the same (except for one) choice of instrument variables as Cassell et al. (2012). We apply 2SLS in Table 5, repeating the same analysis as in Table 3. We use nearly identical instrumental variables (IV's) as those used by Cassell et al. (2012), namely CEO age, new CEO flag, natural logarithm of total assets and firm age, liquidity constraint flag, favorable tax status, maximum state tax rate on individual income, and industry median inside debt measures. We only exclude CEO age as an IV because it is used in the computation of $\mathrm{k}^{*}$, thus creating a mechanical relation between CEO age and our adjusted inside debt measure. In our 2SLS analysis, we first regress $\mathrm{k}$ and $\mathrm{k}^{*}$ on our instruments using equation (3), and then use the predicted values from the first-stage regression results as explanatory variables in equation (2).

In Columns 1-2 of Table 5, we see that $\mathrm{k}^{*}$ has a coefficient of -0.1694 with a tstat of -4.29 , whereas $\mathrm{k}$ has a smaller coefficient of -0.1654 and a t-stat of -4.15 in explaining the $\log$ of total risk in year $t+1$. This pattern of $\mathrm{k}^{*}$ 's superiority can be observed in Columns 3-4 as well. Consistent with the results presented in Table 3, the 
conceptual superiority of $\mathrm{k}^{*}$ is, in general, supported empirically by the results in Table 5. Overall, the results presented in Table 5 support our main hypothesis, $H 1$.

\author{
[Insert Table 5]
}

\title{
4.5. RESULTS FOR INVESTMENT VS. NON-INVESTMENT GRADE FIRMS
}

As hypothesized earlier, we expect $\mathrm{k}^{*}$ to exhibit a better fit for more credit risky firms where DP and RR discount the raw-k to greater degree. To investigate this aspect of our hypothesis, we examine $\mathrm{k}^{*}$ for three subsamples: firms that are non-investment grade (this section); firms that experience credit downgrades (section 4.6); and firms with high credit risk (section 4.7). In all three cases we report results from OLS analysis. We also obtain similar qualitative results for 2SLS analysis.

By separating our sample into investment and non-investment grades, we find, as hypothesized, that $\mathrm{k}^{*}$ performs better for the latter cohort. The difference for our sample split according to Moody's credit ratings can be seen by contrasting the coefficients and t-stats in Columns 1-2 with those in Columns 3-4 of Table 6. Specifically, for the noninvestment grade group (below Baa3), $\mathrm{k}^{*}$ has a coefficient of -0.0477 , larger (in absolute terms) than that of $\mathrm{k}$ at -0.0460 . However, the coefficient for $\mathrm{k}^{*}$ is not larger than the coefficient for $\mathrm{k}$ for the investment grade group (Baa3 or better). While the results reported in Table 6 are limited to the $\log$ of total risk at time $t+1$, similar results are obtained for the other dependent variables. Overall, Table 6, when compared with Table 
3 , shows that the gap between the significance of $\mathrm{k}^{*}$ and $\mathrm{k}$ widens both economically and statistically for non-investment grade firms. ${ }^{23}$ This is consistent with our hypothesis.

\author{
[Insert Table 6]
}

\title{
4.6. RESULTS FOR FIRMS EXPERIENCING CREDIT DOWNGRADES
}

We hypothesize that $\mathrm{k}^{*}$ should outperform $\mathrm{k}$ even further for firms experiencing credit downgrades. To correctly identify these firms, we require firms to have at least two back-to-back annual credit rating observations. The subsample of firms with such observations is 1,092 (out of our 1,984 firms). Of these 1,092 firms, 410 experienced a credit rating downgrade (of one or more "notches"). Table 7 reports OLS analysis for these 410 cases. In general, the results reported are consistent with the notion that $\mathrm{k}^{*}$ outperforms $\mathrm{k}$ for these firms, albeit results for the $\mathrm{t}+3$ variables are statistically insignificant. Moreover, when comparing the coefficients on $\mathrm{k}^{*}$ in Table 7 with those in Table 3, we see that the former are much larger (in absolute value), despite the smaller size of the downgrade subsample. Furthermore, when compared with Table 3, the improvement of $\mathrm{k}^{*}$ over $\mathrm{k}$ appears more prominent, economically and statistically, in the results for $t+1$ (but not for $t+3$ since they are all insignificant). These results are generally consistent with $H 1$ and further suggest that $\mathrm{k}^{*}$ is a superior measure for credit risky firms.

\footnotetext{
${ }^{23}$ We also investigated sample splits by above or equal to Ba3 versus below Ba3, and by above Caa1 versus equal to or below Caa1. Firms are classified as having "distressed debt" if their rating is Caa1 or worse. While the results of our investigation were generally consistent with the hypothesis that $\mathrm{k}^{*}$ outperforms $\mathrm{k}$ for the riskier cohorts, small sample sizes precluded us from making any strong inferences.
} 


\section{[Insert Table 7]}

\subsection{RESULTS FOR CREDIT RISKY FIRMS}

As with non-investment grade firms and firms that experienced credit rating downgrades, we also expect $\mathrm{k}^{*}$ to exhibit improved empirical fit for firms with higherthan-median [1-DP(1-RR)]. After all, [1-DP(1-RR)] is our unique "credit risk adjustment factor," driving the difference between the promised payoffs and the expected payoffs of the inside debt. Table 8 Panel A suggests that for less risky firms, $\mathrm{k}$ and $\mathrm{k}^{*}$ perform similarly. Note that if [1-DP(1-RR)] $=1, \mathrm{k}$ and $\mathrm{k}^{*}$ are identical. In addition, if the firm is safe, the inside debt does not affect the managerial decision. Therefore, the results are less significant than those in Table 3.

We find interesting results in Panel B for credit risky firms. These are much more significant than those in Panel A and in Table 3, suggesting that inside debt does affect the executives' decision in credit risky firms. More importantly, $\mathrm{k}^{*}$ outperforms $\mathrm{k}$ even more in this subsample. This illustrates that the riskiness of inside debt is an important consideration, especially for credit risky firms.

\section{[Insert Table 8]}

\section{Credit Crisis and Robustness Tests}

In this section we conduct robustness checks to further test the relationship between $\mathrm{k}^{*}$ and firm risk using OLS and 2SLS, and we discuss the results. We also 
outline other robustness checks involving the derivation of DP and RR from credit default swap spreads.

\subsection{CREDIT CRISIS TEST}

Assuming that the current credit crisis was an unanticipated exogenous shock to most individual firms, we use it as a natural experiment to address endogeneity (e.g., Campello, Graham, and Harvey, 2010; Ivashina and Scharfstein, 2010), and investigate whether the relation between executive conservatism (aggression) and credit riskadjusted inside debt strengthens (wanes) during the crisis. We separate our sample into two sub-periods: the crisis period (2007 and 2008), and the non-crisis period (2006, 2009 and 2010). We then conduct 2SLS. The instruments used include new CEO flag, natural logarithm of total assets and firm age, liquidity constraint flag, favorable tax status, maximum state tax rate on individual income, and industry median inside debt measures. In Table 9, we first regress $\mathrm{k}$ and $\mathrm{k}^{*}$ on our instruments, and then use the predicted values from the first-stage regression results as explanatory variables. Results are largely consistent with the inference that executives become more conservative during a credit crisis. For example, the t-statistics on the $\mathrm{k}^{*}$ variables are generally greater during the crisis period, especially when the dependent variable is total risk. Also, results indicate that $\mathrm{k}^{*}$ is still more robust than its original $\mathrm{k}$ as an explanatory variable throughout Table 9.

[Insert Table 9] 


\subsection{RESULTS OF ADDITIONAL ROBUSTNESS TESTS}

As noted earlier, we also obtain DP and RR - for the full sample (1,984 firmyears) - by using alternative ratings data and their associated historical default probabilities and recovery rates provided by Standard and Poor's. Furthermore, for a subsample of firms (318 firm years) we were able to impute DP and RR from 5-year credit default swap (CDS) spreads as provided by Bloomberg. Here we use firms whose inside debt maturity is close to five years. The method used to impute DP and RR from CDS spreads follows Hull (2012, pages 554-555). ${ }^{24}$ For the sake of brevity, we do not detail here the test results of relating future stock return volatility and $\mathrm{k}^{*}$ as measured using these alternative values of DP and RR. Instead, we merely report that the robustness test results are highly consistent with those reported in all of the tables that are presented here. Results are available upon request. Given the efficiency of the credit markets and the rarity of split ratings, it is not surprising that results are similar when adjusting inside debt using data from different major ratings firms as well as CDS spreads. The values of the product [DP $x(1-R R)]$ obtained from different rating agencies, as well as from CDS spreads, are all highly correlated. ${ }^{25}$

\footnotetext{
${ }^{24} \mathrm{DP}$ can be readily implied from CDS spreads. To obtain RR, we rely on the empirical fact that implied default probabilities are approximately proportional to $1 /(1-\mathrm{RR})$.

${ }^{25}$ It is plausible that more credit risky firms are more conservative due to their debt restrictions/covenants, rather than because of CEO choice/inside debt. However, tests involving raw-k already reflect restrictions associated with the firm's outside debt. Since it is the same debt for both tests involving $\mathrm{k}^{*}$ and $\mathrm{k}$, the result that $\mathrm{k}^{*}$ fits better than $\mathrm{k}$ suggests that executives must be more conservative, even if their outside debt precludes aggression. We show incremental explanatory power when using $\mathrm{k}^{*}$.
} 
In unreported tests, we examined the other three $\mathrm{k}$ measures in Cassell et al. (2011): k_indicator, k_relative, k_relative_CA. We obtained similar comparative results by adjusting for the credit risk of the inside debt in each of the three cases. Different forms of $\mathrm{k}^{*}$ perform consistently better than comparable forms of $\mathrm{k}$, especially for firms with weaker credit.

We next investigate the possibility that a change in CEO may be driving our result that CEO aggression is inversely related to $\mathrm{k}^{*}$. For all tests reported in Tables 3-7, we separately investigate the 1,506 sample firms that experienced no change in CEO during the test period and find no difference in test results. For example, consistent with results reported in Table $6, \mathrm{k}^{*}$ outperforms $\mathrm{k}$ for non-investment grade firms within these 1,506 firms. This suggests that the possibility of differing degrees of managerial risk aversion, occasioned by CEO turnover, does not change our findings. Once again, our metric $\mathrm{k}^{*}$ shows improvement over $\mathrm{k}$ in explaining future equity return volatility.

\section{Conclusion}

Jensen and Meckling's (1976) theory of inside debt incentives predicts that more (less) credit risk-adjusted inside debt - and not merely the level of inside debt per se motivates executives to be more (less) conservative. In this framework, our study makes three contributions to the literature on executive aggression and inside debt. First, to our knowledge, our study is the first one to provide a metric that reflects a credit riskadjusted level of inside debt, and is therefore conceptually superior to previously used 
metrics. Second, we show that the relation between our metric and future equity volatility is statistically and economically stronger than previously used metrics, especially for high-credit risk firms. In particular, we construct a metric, $\mathrm{k}^{*}$, that accounts for the credit risk-adjusted level of inside debt, and find that it is more powerfully related to corporate conservatism (as captured by future firm equity return volatility) than the commonly used raw-k metric. This relationship is more prominent for non-investment grade firms, firms experiencing a credit downgrade, and firms with high credit risk. As such, inferences from our study are important to researchers, practitioners, and policy makers when addressing the issue of optimal executive compensation, especially the use of inside debt. Third, we show that the relation between executive conservatism and inside debt heightens during the credit crisis.

Future research efforts should examine the relation between other corporate policies, such as accounting conservatism, tax aggression, diversification, research and development expenditures, and asset liquidity, and our $\mathrm{k}^{*}$ metric, as well as the relation between corporate governance and the credit quality of inside debt. 


\section{References}

Abhishek, S., S. Armitage, and J. Hagendorff. 2014. CEO inside debt holdings and riskshifting: Evidence from bank payout policies. Journal of Banking and Finance 47, 4153.

Allgood, S. and K.A. Farrell, 2000. The effect of CEO tenure on the relation between firm performance and turnover. The Journal of Financial Research 23, 373-390.

Anantharaman, D., V. Fang, and G. Gong. 2013. Inside debt and the design of corporate debt contracts. Management Science 60, 1260-1280.

Antia, M., Pantzalis, C., Park, J.C., 2010. CEO decision horizon and firm performance: an empirical investigation. Journal of Corporate Finance 16, 288-301.

Bebchuk, L.A., Jolls, C., 1999. Managerial value diversion and shareholder wealth. Journal of Law, Economics, and Organization 15, 487-502.

Belsley, D. A., 1991. Conditioning diagnostics - Collinearity and weak data in regression. Wiley series in probability and mathematical statistics. New Jersey: WileyInterscience Publication.

Berle, A.A., Means, G.C., 1932. The Modern Corporation and Private Property, MacMillan, New York.

Black, F., Scholes, M., 1973. The pricing of options and corporate liabilities. Journal of Political Economy 81, 637-654.

Cassell, C., S. Huang, J. Sanchez, and M. Stuart. 2012. Seeking safety: The relation between CEO inside debt holdings and the riskiness of firm investment and financial policies. Journal of Financial Economics 103, 588-610.

Campello, M., Graham, J.R., Harvey, C.R., 2010. The real effects of financial constraints: evidence from a financial crisis. Journal of Financial Economics 97 (3), 470-487.

Chen, F., Dou, Y., Wang, X., 2010. Executive Inside Debt Holdings and Creditors' Demand for Pricing and Non-pricing Protections, Working Paper, University of Toronto and Chinese University of Hong Kong.

Chen, D., Zheng, Y., 2014. CEO Tenure and Risk-taking. Global Business and Finance Review. 19(1), 1-27. 
Chi, S., S. Huang, and J. Sanchez. 2014. CEO inside debt incentives and corporate tax policy. Working paper, University of Arkansas.

Choy, H., J. Lin, and M. Officer. 2014. Does freezing a defined benefit pension plan affect firm risk? Journal of Accounting and Economics 57, 1-21.

Coles, J., N. Naveen, and L. Naveen. 2006. Managerial incentives and risk-taking. Journal of Financial Economics 79, 431-468.

Coles, J., Daniel, N., Naveen, L., 2013. Calculation of Compensation Incentives and Firm-related Wealth using Execucomp: Data, Program, and Explanation.

Core, J., Guay, W., 1999. The use of equity grants to manage optimal equity incentive levels. Journal of Accounting and Economics 28, 151-184.

Core, J., Guay, W., 2002. Estimating the value of employee stock option portfolios and their sensitivities to price and volatility. Journal of Accounting Research 40, 613-630.

Daniel, N., Li, Y., and Naveen, L. 2013. No asymmetry in pay for luck. Working Paper.

Edmans, A., and Q. Liu, 2011. Inside debt. Review of Finance 15, 75-102.

Eisdorfer, A., C. Giaccotto, and R. White. 2013. Capital structure, executive compensation, and investment efficiency. Journal of Banking and Finance 37, 549-562.

Farebrother, R.W., 1975. The minimum mean square linear estimator and ridge regression. Technometrics, 127-128.

Farrell, K. A., D. A. Whidbee, 2002. Monitoring by the financial press and forced CEO turnover. Journal of Banking and Finance 26, 2249-2276.

Goyal, A., Santa-Clara, P., 2003. Idiosyncratic risk matters! Journal of Finance 58, 9751007.

Guay, W. 1999. The Sensitivity of CEO Wealth to Equity Risk: An Analysis of the Magnitude and Determinants. Journal of Financial Economics 53: 43-71.

Hoerl, A. E. and Kennard, R.W., 1970a. Ridge regression: biased estimation for nonorthogonal problems, Technometrics, 12, 55-67. 
Hoerl, A. E. and Kennard, R. W., 1970b. Ridge regression: applications to nonorthogonal problems, Technometrics, 12, 69-82.

Hull, J. 2012. Options, Futures, and Other Derivatives, Prentice Hall, $8^{\text {th }}$ edition.

Huson, M.R., P.H. Malatesta and R. Parrino, 2004. Managerial succession and firm performance. Journal of Financial Economics 74, 237-275.

Ivashina, V., Scharfstein, D., 2010. Bank lending during the financial crisis of 2008. Journal of Financial Economics 97, 319-338.

Jensen, M. and W. Meckling. 1976. Theory of the firm: Managerial behavior, agency costs, and ownership structure. Journal of Financial Economics 3, 305-360.

Kabir, R., H. Li, and Y. Veld-Merkoulova. 2013. Executive compensation and the cost of debt. Journal of Banking and Finance 37, 2893-2907.

Kubick, T., G. Lockhart, and T. Robinson. 2014. Does inside debt moderate corporate tax avoidance? Working paper, University of Kansas.

Kutner, M. H., Nachtsheim, C. J., Neter, J., and Li, W., 2004. Applied linear statistical models (5th ed.). New York: McGraw-Hill.

Lambert, R.A., Larcker, D.F., 1987. An analysis of the use of accounting and market measures of performance in executive-compensation contracts. Journal of Accounting Research 25, 85-129.

Liu, Y., D. Mauer, and Y. Zhang. 2014. Firm cash holdings and CEO inside debt. Journal of Banking and Finance 42, 83-100.

Lowerre, J.M., 1974. On the mean square error of parameter estimates for some biased estimators. Technometrics, 461-464.

Merton, R.C., 1973. Theory of rational option pricing. The Bell Journal of Economics and Management Science 4, 141-183.

Moody's, 2012. Corporate Default and Recovery Rates, 1920-2011. Moody's Investors Service, 1-66.

Morck, R., Schleifer, A., Vishny, R.W., 1988. Management ownership and market valuation: an empirical analysis. Journal of Financial Economics 20, 293-315. 
Murphy, K., 1985. Corporate performance and managerial remuneration: an empirical investigation. Journal of Accounting and Economics 7, 11-42.

Sundaram, R., and D. Yermack. 2007. Pay me later: Inside debt and its role in managerial compensation. Journal of Finance 62, 1551-1558.

Vinod, H.D., 1978. A survey of ridge regression and related techniques for improvements over ordinary least squares. Review of Economics and Statistics 60 (1), $121-131$.

Wang, C., Xie, F., Xin, X., 2010. Managerial Ownership of Debt and Accounting Conservatism, Working Paper, Chinese University of Hong Kong and George Mason University.

Wei, C., and D. Yermack. 2011. Investor reactions to CEOs' inside debt incentives, Review of Financial Studies 24, 3813-3840.

Xu, Y., Malkiel, B.G., 2003. Investigating the behavior of idiosyncratic volatility. Journal of Business 76, 613-644. 
Table 1 Summary statistics

This table presents descriptive statistics for sample period of 2006-2010. Variable calculation methodology and definitions are provided in Appendices A and B.

\begin{tabular}{|c|c|c|c|c|c|c|}
\hline & $\mathrm{N}$ & Mean & Std.Dev & Q1 & Median & Q3 \\
\hline Log of total risk $t+1$ & 1,984 & -7.35 & 1.01 & -8.08 & -7.45 & -6.69 \\
\hline Log of total risk $t+1$ to $t+3$ & 1,984 & -7.28 & 1.10 & -7.96 & -7.35 & -6.75 \\
\hline Log of idiosyncratic risk $\mathrm{t}+1$ & 1,984 & -7.89 & 1.07 & -8.66 & -8.02 & -7.25 \\
\hline Log of idiosyncratic risk $t+1$ to $t+3$ & 1,984 & -7.78 & 1.21 & -8.51 & -7.88 & -7.24 \\
\hline CEO to firm debt/equity ratio $(\mathrm{k})$ & 1,984 & 2.21 & 6.68 & 0.16 & 0.60 & 1.67 \\
\hline Adjusted CEO to firm debt/equity $\left(\mathrm{k}^{*}\right)$ & 1,984 & 2.12 & 6.25 & 0.15 & 0.57 & 1.62 \\
\hline CEO stock holdings ( $\$$ thousands) & 1,984 & $56,057.67$ & $206,216.95$ & $5,413.24$ & $13,386.34$ & $30,479.49$ \\
\hline CEO option holdings ( $\$$ thousands) & 1,984 & $19,891.86$ & $34,112.71$ & $1,766.89$ & $8,238.87$ & $21,868.28$ \\
\hline CEO equity holdings (CEO EH) (\$thousands) & 1,984 & $76,280.85$ & $220,369.06$ & $10,770.34$ & $25,121.22$ & $56,466.95$ \\
\hline Total current comp (salary+bonus)(\$thousands) & 1,984 & $1,225.81$ & 952.56 & 800 & 1,000 & $1,249.02$ \\
\hline CEO vega (\$thousands) & 1,984 & 207.07 & 270.71 & 31.34 & 105.35 & 272.23 \\
\hline CEO delta (\$thousands) & 1,984 & 856.63 & $2,276.79$ & 117.91 & 299.28 & 719.24 \\
\hline CEO vega/delta ratio & 1,984 & 9.31 & 26.02 & 0.57 & 1.85 & 5.68 \\
\hline Annual return & 1,984 & 0.06 & 0.53 & -0.22 & 0.04 & 0.24 \\
\hline Total assets (\$millions) & 1,984 & $16,517.89$ & $36,401.95$ & $2,670.47$ & $5,900.46$ & $16,921.54$ \\
\hline Cash surplus & 1,984 & 0.07 & 0.07 & 0.03 & 0.06 & 0.11 \\
\hline Debt/equity ratio & 1,984 & 0.76 & 2.33 & 0.15 & 0.33 & 0.71 \\
\hline Market-to-book ratio & 1,984 & 2.61 & 4.73 & 1.36 & 1.99 & 3.18 \\
\hline Sales Growth & 1,984 & 1.05 & 0.19 & 0.97 & 1.05 & 1.12 \\
\hline Firm age (years) & 1,984 & 37.18 & 18.11 & 19.01 & 39.02 & 57.04 \\
\hline
\end{tabular}


Table 2 Association between the relative CEO debt-to equity ratio and the volatility of future stock returns

This table presents OLS regression results for our sample period of 2006-2010 in which the dependent variable is Log of total risk or Log of idiosyncratic risk. In Panel A, the dependent variable is measured in year $t+1$, and in Panel B, the dependent variable is measured in years $t+1$ through $t+3$. Variable calculation methodology and definitions are provided in Appendices A and B. For detailed definitions of the four k measures, please refer to Cassell et al. (2011). Each model includes industry (two-digit SIC) and year fixed effects. ${ }^{* * *},{ }^{* *}$, and $*$ represent significance at the $1 \%, 5 \%$, and $10 \%$ levels, respectively.

\begin{tabular}{|c|c|c|c|c|c|c|c|c|}
\hline Panel A & (1) & (2) & (3) & (4) & $(5)$ & (6) & (7) & (8) \\
\hline & Log of idios & cratic risk $\mathrm{t}+1$ & & & Log of total & sk t+1 & & \\
\hline & $\mathrm{k}$ & k_indicator & k_relative & k_relative_CA & $\mathrm{k}$ & k_indicator & k_relative & k_relative_CA \\
\hline Log of CEO to firm debt/equity ratio & $-0.0327 * * *$ & & & & $-0.0322 * * *$ & & & \\
\hline & $(-3.46)$ & & & & $(-3.94)$ & & & \\
\hline CEO to firm debt/equity ratio $>1$ & & $-0.0836 * *$ & & & & $-0.0778 * * *$ & & \\
\hline & & $(-2.50)$ & & & & $(-2.67)$ & & \\
\hline Log of CEO relative incentive ratio & & & $-0.0210 * *$ & & & & $-0.0214 * *$ & \\
\hline & & & $(-2.15)$ & & & & $(-2.54)$ & \\
\hline Log of CEO relative incentive ratio CA & & & & -0.0026 & & & & -0.0043 \\
\hline & & & & $(-0.28)$ & & & & $(-0.53)$ \\
\hline Annual return & $0.1036 * * *$ & $0.1051 * * *$ & $0.1066 * * *$ & $0.1096 * * *$ & $0.0855 * * *$ & $0.0872 * * *$ & $0.0883 * * *$ & $0.0912 * * *$ \\
\hline & -5.26 & -5.35 & -5.43 & -5.61 & -4.98 & -5.1 & -5.16 & -5.37 \\
\hline Cash surplus & $-2.3452 * * *$ & $-2.4161 * * *$ & $-2.4091 * * *$ & $-2.4905 * * *$ & $-2.3214 * * *$ & $-2.3958 * * *$ & $-2.3811 * * *$ & $-2.458 * * *$ \\
\hline & $(-9.59)$ & $(-9.85)$ & $(-9.80)$ & $(-10.08)$ & $(-11.53)$ & $(-11.81)$ & $(-11.78)$ & $(-12.12)$ \\
\hline CEO vega/delta ratio & -0.0006 & 0.0000 & -0.0003 & 0.0002 & $-0.0007 *$ & 0.0000 & -0.0004 & 0.0002 \\
\hline & $(-1.44)$ & -0.04 & $(-0.70)$ & -0.6 & $(-1.70)$ & $(-0.02)$ & $(-0.93)$ & -0.53 \\
\hline Debt/equity ratio & $0.1493 * * *$ & $0.1523 * * *$ & $0.1517 * * *$ & $0.1544 * * *$ & $0.1216 * * *$ & $0.1246 * * *$ & $0.1238 * * *$ & $0.1263 * * *$ \\
\hline & -11.4 & -11.58 & -11.47 & -11.6 & -10.98 & -11.14 & -11.03 & -11.13 \\
\hline Log of firm age & $-0.1331 * * *$ & $-0.1375 * * *$ & $-0.1386 * * *$ & $-0.1459 * * *$ & $-0.076 * * *$ & $-0.0808 * * *$ & $-0.0811 * * *$ & $-0.0881 * * *$ \\
\hline & $(-4.04)$ & $(-4.16)$ & $(-4.19)$ & $(-4.40)$ & $(-2.73)$ & $(-2.90)$ & $(-2.90)$ & $(-3.16)$ \\
\hline Log of total assets & $-0.1959 * * *$ & $-0.1936 * * *$ & $-0.1952 * * *$ & $-0.1922 * * *$ & $-0.1693 * * *$ & $-0.167 * * *$ & $-0.1688 * * *$ & $-0.1663 * * *$ \\
\hline & $(-14.02)$ & $(-13.77)$ & $(-13.86)$ & $(-13.27)$ & $(-13.60)$ & $(-13.33)$ & $(-13.40)$ & $(-12.79)$ \\
\hline Log of total current comp(salary+bonus) & -0.0368 & -0.0386 & -0.0373 & -0.0393 & -0.0238 & -0.0257 & -0.0242 & -0.0259 \\
\hline & $(-1.01)$ & $(-1.07)$ & $(-1.03)$ & $(-1.08)$ & $(-0.72)$ & $(-0.78)$ & $(-0.73)$ & $(-0.78)$ \\
\hline Market-to-book ratio & $-0.0123 * * *$ & $-0.0124 * * *$ & $-0.0124 * * *$ & $-0.0125^{* * * *}$ & $-0.01 * * *$ & $-0.0101 * * *$ & $-0.0101 * * *$ & $-0.0102 * * *$ \\
\hline & $(-3.54)$ & $(-3.62)$ & $(-3.59)$ & $(-3.64)$ & $(-3.20)$ & $(-3.23)$ & $(-3.23)$ & $(-3.25)$ \\
\hline Sales growth & -0.0547 & -0.0566 & -0.052 & -0.0504 & -0.0771 & -0.0785 & -0.0744 & -0.0732 \\
\hline & $(-0.69)$ & $(-0.71)$ & $(-0.65)$ & $(-0.63)$ & $(-1.18)$ & $(-1.20)$ & $(-1.14)$ & $(-1.11)$ \\
\hline
\end{tabular}




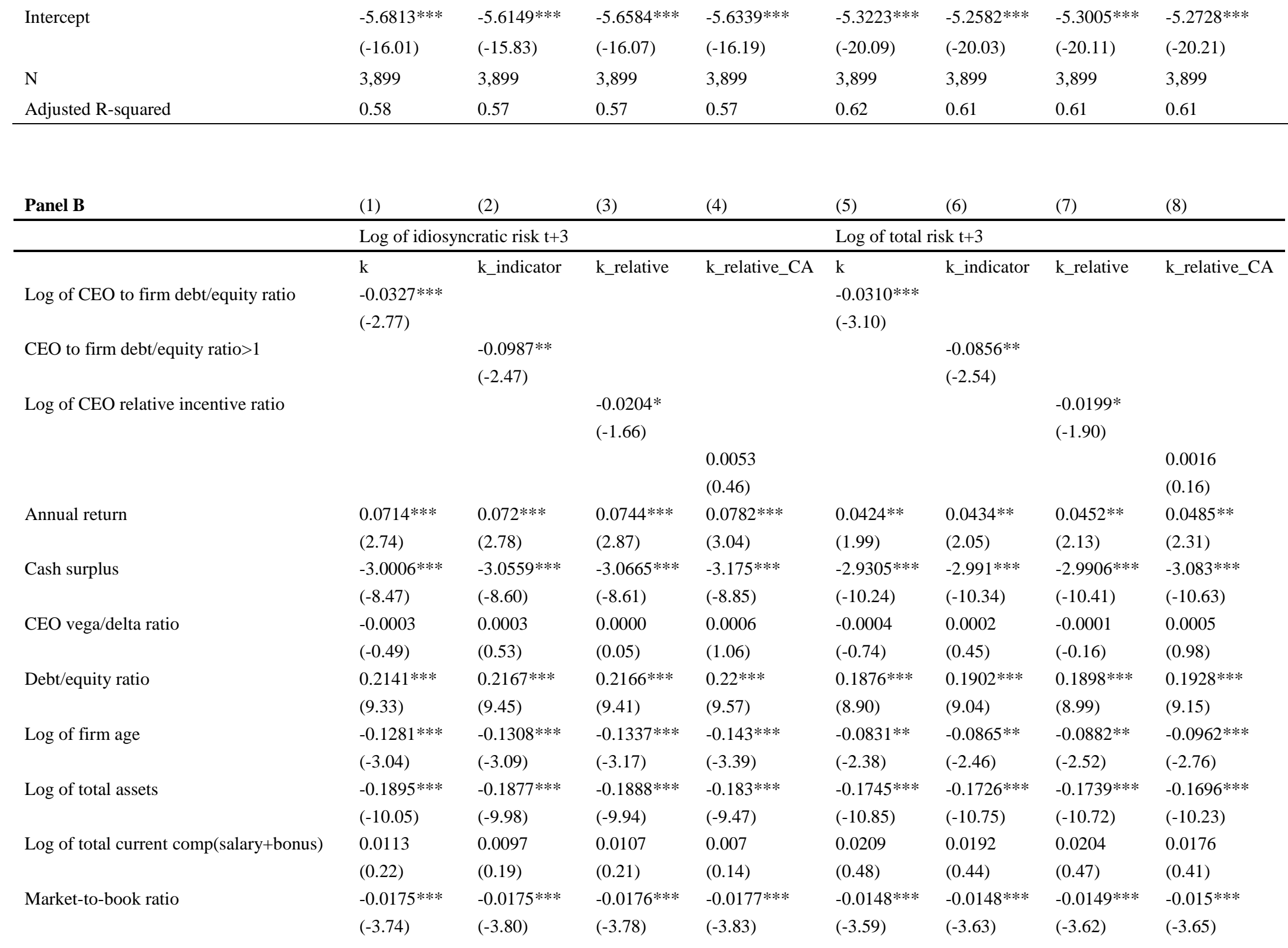




\begin{tabular}{|c|c|c|c|c|c|c|c|c|}
\hline \multirow[t]{2}{*}{ Sales growth } & -0.1197 & -0.1227 & -0.1168 & -0.1137 & -0.1156 & -0.1179 & -0.113 & -0.1107 \\
\hline & $(-1.27)$ & $(-1.30)$ & $(-1.24)$ & $(-1.20)$ & $(-1.46)$ & $(-1.48)$ & $(-1.42)$ & $(-1.38)$ \\
\hline \multirow[t]{2}{*}{ Intercept } & $-6.3011 * * *$ & $-6.2306 * * *$ & $-6.2777 * * *$ & $-6.2664 * * *$ & $-5.9439 * * *$ & $-5.8793 * * *$ & $-5.9223 * * *$ & $-5.9054 * * *$ \\
\hline & $(-15.91)$ & $(-15.72)$ & $(-15.92)$ & $(-15.92)$ & $(-18.34)$ & $(-18.23)$ & $(-18.34)$ & $(-18.27)$ \\
\hline $\mathrm{N}$ & 3,899 & 3,899 & 3,899 & 3,899 & 3,899 & 3,899 & 3,899 & 3,899 \\
\hline Adjusted R-squared & 0.51 & 0.51 & 0.50 & 0.50 & 0.55 & 0.55 & 0.55 & 0.55 \\
\hline
\end{tabular}


Table 3 Comparison between $k$ and $k^{*}$ as measure of CEO inside debt - OLS

This table presents OLS regression results for our sample period of 2006-2010 in which the dependent variable is Log of total risk or Log of idiosyncratic risk and the independent variables of interest are two inside debt measures: CEO to firm debt/equity ratio (k) and adjusted CEO to firm debt/equity ratio ( $\left.\mathrm{k}^{*}\right)$. In Columns 1-2, the dependent variable is measured in year $t+1$. In Columns 3-4 the dependent variable is measured in years $t+1$ through $t+3$. Variable calculation methodology and definitions are provided in Appendix A and Appendix B. Each model includes industry (two-digit SIC) and year fixed effects. ${ }^{* * *},{ }^{* *}$, and $*$ represent significance at the $1 \%, 5 \%$, and $10 \%$ levels, respectively.

\begin{tabular}{|c|c|c|c|c|c|c|c|c|}
\hline \multirow[b]{3}{*}{ Controls } & \multirow{2}{*}{\multicolumn{2}{|c|}{$\begin{array}{l}(1) \quad(2) \\
\text { Log of total risk } t+1\end{array}$}} & \multirow{2}{*}{\multicolumn{2}{|c|}{$\frac{\text { (3) }}{\text { Log of idiosyncratic risk } t+1}$}} & \multirow{2}{*}{\multicolumn{2}{|c|}{$\frac{(5)}{\text { Log of total risk } t+3}$}} & \multirow{2}{*}{\multicolumn{2}{|c|}{$\frac{(7)}{\text { Log of idiosyncratic risk } t+3}$}} \\
\hline & & & & & & & & \\
\hline & $\mathrm{k}^{*}$ & $\mathrm{k}$ & $\mathrm{k}^{*}$ & $\mathrm{k}$ & $\mathrm{k}^{*}$ & $\mathrm{k}$ & $\mathrm{k}^{*}$ & $\mathrm{k}$ \\
\hline Log of Adjusted CEO to firm debt/equity ratio & $\begin{array}{l}-0.0467 * * * \\
(-3.74)\end{array}$ & & $\begin{array}{l}-0.0435 * * * \\
(-3.14)\end{array}$ & & $\begin{array}{l}-0.0397 * * \\
(-2.49)\end{array}$ & & $\begin{array}{l}-0.0342^{*} \\
(-1.87)\end{array}$ & \\
\hline Log of CEO to firm debt/equity ratio & & $\begin{array}{l}-0.0460 * * * \\
(-3.68)\end{array}$ & & $\begin{array}{l}-0.0424 * * * \\
(-3.07)\end{array}$ & & $\begin{array}{l}-0.0393 * * \\
(-2.46)\end{array}$ & & $\begin{array}{l}-0.0338^{*} \\
(-1.85)\end{array}$ \\
\hline Annual return & $\begin{array}{l}0.0969 * * * \\
(3.57)\end{array}$ & $\begin{array}{l}0.097 * * * \\
(3.58)\end{array}$ & $\begin{array}{l}0.1226 * * * \\
(3.97)\end{array}$ & $\begin{array}{l}0.1227 * * * \\
(3.97)\end{array}$ & $\begin{array}{l}0.0439 \\
(1.24)\end{array}$ & $\begin{array}{l}0.0439 \\
(1.24)\end{array}$ & $\begin{array}{l}0.0782 * * \\
(2.02)\end{array}$ & $\begin{array}{l}0.0783 * * \\
(2.02)\end{array}$ \\
\hline Cash surplus & $\begin{array}{l}-2.5753 * * * \\
(-8.47)\end{array}$ & $\begin{array}{l}-2.5824 * * * \\
(-8.49)\end{array}$ & $\begin{array}{l}-2.3046^{* * * *} \\
(-6.19)\end{array}$ & $\begin{array}{l}-2.3133 * * * \\
(-6.22)\end{array}$ & $\begin{array}{l}-3.5382 * * * \\
(-7.38)\end{array}$ & $\begin{array}{l}-3.5428 * * * \\
(-7.39)\end{array}$ & $\begin{array}{l}-3.3501 * * * \\
(-5.88)\end{array}$ & $\begin{array}{l}-3.3543 * * * \\
(-5.89)\end{array}$ \\
\hline CEO vega/delta ratio & $\begin{array}{l}-0.0008 \\
(-1.24)\end{array}$ & $\begin{array}{l}-0.0007 \\
(-1.18)\end{array}$ & $\begin{array}{l}-0.0005 \\
(-0.75)\end{array}$ & $\begin{array}{l}-0.0005 \\
(-0.69)\end{array}$ & $\begin{array}{l}-0.0001 \\
(-0.05)\end{array}$ & $\begin{array}{l}0.0000 \\
(-0.03)\end{array}$ & $\begin{array}{l}0.0004 \\
(0.30)\end{array}$ & $\begin{array}{l}0.0004 \\
(0.32)\end{array}$ \\
\hline Debt/equity ratio & $\begin{array}{l}0.1017 * * * \\
(9.90)\end{array}$ & $\begin{array}{l}0.1018^{* * *} \\
(9.91)\end{array}$ & $\begin{array}{l}0.1231 * * * \\
(10.67)\end{array}$ & $\begin{array}{l}0.1233 * * * \\
(10.68)\end{array}$ & $\begin{array}{l}0.1847 * * * \\
(7.00)\end{array}$ & $\begin{array}{l}0.1847 * * * \\
(7.00)\end{array}$ & $\begin{array}{l}0.2105^{* * * *} \\
(7.48)\end{array}$ & $\begin{array}{l}0.2106^{* * * *} \\
(7.49)\end{array}$ \\
\hline Log of firm age & $\begin{array}{l}-0.1346 * * * \\
(-3.38)\end{array}$ & $\begin{array}{l}-0.1351 * * * \\
(-3.40)\end{array}$ & $\begin{array}{l}-0.1726 * * * \\
(-3.68)\end{array}$ & $\begin{array}{l}-0.1732 * * * \\
(-3.69)\end{array}$ & $\begin{array}{l}-0.1512 * * * \\
(-3.26)\end{array}$ & $\begin{array}{l}-0.1515 * * * \\
(-3.27)\end{array}$ & $\begin{array}{l}-0.1905^{* * *} \\
(-3.42)\end{array}$ & $\begin{array}{l}-0.1908 * * * \\
(-3.42)\end{array}$ \\
\hline Log of total assets & $\begin{array}{l}-0.1174 * * * \\
(-6.19)\end{array}$ & $\begin{array}{l}-0.1177^{* * *} \\
(-6.20)\end{array}$ & $\begin{array}{l}-0.132 * * * \\
(-6.35)\end{array}$ & $\begin{array}{l}-0.1323 * * * \\
(-6.36)\end{array}$ & $\begin{array}{l}-0.1176 * * * \\
(-4.95)\end{array}$ & $\begin{array}{l}-0.1178 * * * \\
(-4.96)\end{array}$ & $\begin{array}{l}-0.1219 * * * \\
(-4.48)\end{array}$ & $\begin{array}{l}-0.1221 * * * \\
(-4.49)\end{array}$ \\
\hline Log of total current comp(salary+bonus) & $\begin{array}{l}-0.0336 \\
(-0.76)\end{array}$ & $\begin{array}{l}-0.0343 \\
(-0.77)\end{array}$ & $\begin{array}{l}-0.0524 \\
(-1.13)\end{array}$ & $\begin{array}{l}-0.053 \\
(-1.14)\end{array}$ & $\begin{array}{l}0.0174 \\
(0.32)\end{array}$ & $\begin{array}{l}0.0168 \\
(0.31)\end{array}$ & $\begin{array}{l}0.0087 \\
(0.15)\end{array}$ & $\begin{array}{l}0.0082 \\
(0.14)\end{array}$ \\
\hline Market-to-book ratio & $\begin{array}{l}-0.0049 * \\
(-1.69)\end{array}$ & $\begin{array}{l}-0.0049 * \\
(-1.69)\end{array}$ & $\begin{array}{l}-0.0063 * * \\
(-2.01)\end{array}$ & $\begin{array}{l}-0.0063 * * \\
(-2.01)\end{array}$ & $\begin{array}{l}-0.0057^{*} \\
(-1.68)\end{array}$ & $\begin{array}{l}-0.0057^{*} \\
(-1.68)\end{array}$ & $\begin{array}{l}-0.0065^{*} \\
(-1.77)\end{array}$ & $\begin{array}{l}-0.0065^{*} \\
(-1.77)\end{array}$ \\
\hline Sales growth & $\begin{array}{l}-0.0665 \\
(-0.69)\end{array}$ & $\begin{array}{l}-0.0668 \\
(-0.69)\end{array}$ & $\begin{array}{l}-0.0782 \\
(-0.67)\end{array}$ & $\begin{array}{l}-0.0784 \\
(-0.67)\end{array}$ & $\begin{array}{l}0.0246 \\
(0.17)\end{array}$ & $\begin{array}{l}0.0243 \\
(0.17)\end{array}$ & $\begin{array}{l}-0.0064 \\
(-0.04)\end{array}$ & $\begin{array}{l}-0.0066 \\
(-0.04)\end{array}$ \\
\hline Intercept & $\begin{array}{l}-5.6789 * * * \\
(-18.72)\end{array}$ & $\begin{array}{l}-5.6671 * * * \\
(-18.71)\end{array}$ & $\begin{array}{l}-6.111 * * * \\
(-18.72)\end{array}$ & $\begin{array}{l}-6.0993 * * * \\
(-18.72)\end{array}$ & $\begin{array}{l}-6.3439 * * * \\
(-16.99)\end{array}$ & $\begin{array}{l}-6.3343 * * * \\
(-16.98)\end{array}$ & $\begin{array}{l}-6.7045^{* * *} \\
(-15.99)\end{array}$ & $\begin{array}{l}-6.6962 * * * \\
(-15.99)\end{array}$ \\
\hline $\mathrm{N}$ & 1,984 & 1,984 & 1,984 & 1,984 & 1,984 & 1,984 & 1,984 & 1,984 \\
\hline Adjusted R-squared & 0.61 & 0.61 & 0.56 & 0.56 & 0.56 & 0.56 & 0.53 & 0.53 \\
\hline
\end{tabular}


Table 4 Horse Race: $k$ vs. $k^{*}$

This table presents results based on OLS regressions in Panel A and Ridge regressions in Panel B. The dependent variable is the Log of total risk or Log of idiosyncratic risk and the independent variables are our two inside debt measures: Log of CEO to firm debt/equity ratio (k) and Log of Adjusted CEO to firm debt/equity ratio $\left(\mathrm{k}^{*}\right)$. Variable calculation methodology and definitions are provided in Appendices A and B. Each model includes industry (two-digit SIC) and year fixed effects. $* * *, * *$, and $*$ represent significance at the $1 \%, 5 \%$, and $10 \%$ levels, respectively.

\begin{tabular}{|c|c|c|c|c|c|}
\hline Panel A OLS & $(1)$ & $(2)$ & (3) & $(4)$ & $(5)$ \\
\hline & $\begin{array}{l}\text { Log of idiosyncratic risk } \\
t+1\end{array}$ & $\begin{array}{l}\text { Log of idiosyncratic risk } \\
t+3\end{array}$ & $\begin{array}{l}\text { Log of total risk } \\
t+1\end{array}$ & $\begin{array}{l}\text { Log of total risk } \\
t+3\end{array}$ & $\begin{array}{l}\text { Collinearity } \\
\text { Statistics (VIF) }\end{array}$ \\
\hline \multirow[t]{2}{*}{ Log of Adjusted CEO to firm debt/equity ratio } & $-0.4384 *$ & -0.1256 & -0.3089 & -0.1554 & 804.437 \\
\hline & $(-1.80)$ & $(-0.46)$ & $(-1.30)$ & $(-0.61)$ & \\
\hline \multirow[t]{2}{*}{ Log of CEO to firm debt/equity ratio } & 0.3882 & 0.084 & 0.2617 & 0.1122 & 801.177 \\
\hline & $(1.59)$ & $(0.31)$ & $(1.10)$ & $(0.44)$ & \\
\hline \multirow[t]{2}{*}{ CEO Vega/delta ratio } & -0.001 & 0.000 & -0.0009 & -0.0002 & 1.459 \\
\hline & $(-1.46)$ & $(-0.01)$ & $(-1.35)$ & $(-0.17)$ & \\
\hline \multirow[t]{2}{*}{ Log of total current comp(salary+bonus) } & -0.064 & 0.0034 & -0.0393 & 0.0171 & 1.649 \\
\hline & $(-1.35)$ & $(0.05)$ & $(-0.88)$ & $(0.30)$ & \\
\hline \multirow[t]{2}{*}{ Log of firm age } & $-0.16 * * *$ & $-0.1849 * * *$ & $-0.1055 * *$ & $-0.1284 * *$ & 1.417 \\
\hline & $(-3.17)$ & $(-3.08)$ & $(-2.48)$ & $(-2.57)$ & \\
\hline \multirow[t]{2}{*}{ Log of total assets } & $-0.1381 * * *$ & $-0.129 * * *$ & $-0.1272 * * *$ & $-0.1271 * * *$ & 1.831 \\
\hline & $(-6.28)$ & $(-4.82)$ & $(-6.38)$ & $(-5.34)$ & \\
\hline \multirow[t]{2}{*}{ Market-to-book ratio } & $-0.0063 * *$ & $-0.0061 *$ & $-0.005 *$ & -0.0053 & 1.138 \\
\hline & $(-2.03)$ & $(-1.66)$ & $(-1.68)$ & $(-1.53)$ & \\
\hline \multirow[t]{2}{*}{ Sales growth } & -0.0456 & 0.0375 & -0.0468 & 0.0581 & 1.382 \\
\hline & $(-0.39)$ & $(0.23)$ & $(-0.48)$ & $(0.41)$ & \\
\hline \multirow[t]{2}{*}{ Annual return } & $0.1185^{* * *}$ & $0.0735^{*}$ & $0.1004 * * *$ & 0.047 & 1.407 \\
\hline & $(3.97)$ & $(1.94)$ & $(3.72)$ & $(1.32)$ & \\
\hline \multirow[t]{2}{*}{ Debt/equity ratio } & $0.1213 * * *$ & $0.2099 * * *$ & $0.1005 * * *$ & $0.1844 * * *$ & 1.221 \\
\hline & $(10.42)$ & $(7.48)$ & $(9.65)$ & $(6.90)$ & \\
\hline \multirow[t]{2}{*}{ Cash surplus } & $-2.3405^{* * *}$ & $-3.4269 * * *$ & $-2.5275 * * *$ & $-3.543 * * *$ & 1.486 \\
\hline & $(-6.05)$ & $(-5.66)$ & $(-8.04)$ & $(-6.94)$ & \\
\hline \multirow[t]{2}{*}{ Intercept } & $-5.9097 * * *$ & $-6.6957 * * *$ & $-5.5583 * * *$ & $-6.3653 * * *$ & \\
\hline & $(-16.51)$ & $(-13.87)$ & $(-17.10)$ & $(-15.23)$ & \\
\hline $\mathrm{N}$ & 1,984 & 1,984 & 1,984 & 1,984 & \\
\hline Adjusted R-squared & 0.57 & 0.53 & 0.61 & 0.57 & \\
\hline
\end{tabular}




\begin{tabular}{|c|c|c|c|c|}
\hline Panel B Ridge Regression & $(1)$ & $(2)$ & $(3)$ & $(4)$ \\
\hline & $\begin{array}{l}\text { Log of idiosyncratic risk } \\
t+1\end{array}$ & $\begin{array}{l}\text { Log of idiosyncratic risk } \\
\mathrm{t}+3\end{array}$ & Log of total risk $\mathrm{t}+1$ & Log of total risk $\mathrm{t}+3$ \\
\hline \multirow[t]{2}{*}{ Log of Adjusted CEO to firm debt/equity ratio } & $-0.0503 * * *$ & $-0.0264 * *$ & $-0.0448 * * *$ & $-0.0301 * *$ \\
\hline & $(-3.43)$ & $(-2.00)$ & $(-2.85)$ & $(-1.99)$ \\
\hline \multirow[t]{2}{*}{ Log of CEO to firm debt/equity ratio } & -0.0009 & -0.017 & -0.003 & -0.0141 \\
\hline & $(-0.06)$ & $(-1.28)$ & $(-0.19)$ & $(-0.93)$ \\
\hline \multirow[t]{2}{*}{ CEO Vega/delta Ratio } & -0.001 & -0.0001 & -0.0008 & -0.0002 \\
\hline & $(-1.37)$ & $(-0.07)$ & $(-1.31)$ & $(-0.28)$ \\
\hline \multirow[t]{2}{*}{ Log of total current comp(salary+bonus) } & $-0.0695^{*}$ & -0.001 & -0.0429 & 0.0136 \\
\hline & $(-1.76)$ & $(-0.02)$ & $(-1.21)$ & $(0.33)$ \\
\hline \multirow[t]{2}{*}{ Log of firm age } & $-0.1617 * * *$ & $-0.1851 * * *$ & $-0.1069 * * *$ & $-0.1297 * * *$ \\
\hline & $(-5.63)$ & $(-5.52)$ & $(-4.16)$ & $(-4.38)$ \\
\hline \multirow[t]{2}{*}{ Log of total assets } & $-0.1408 * * *$ & $-0.1288 * * *$ & $-0.1289 * * *$ & $-0.1275^{* * *}$ \\
\hline & $(-8.58)$ & $(-6.75)$ & $(-8.75)$ & $(-7.53)$ \\
\hline \multirow[t]{2}{*}{ Market-to-book ratio } & $-0.0061 *$ & -0.0057 & -0.005 & -0.0051 \\
\hline & $(-1.73)$ & $(-1.39)$ & $(-1.58)$ & $(-1.39)$ \\
\hline \multirow[t]{2}{*}{ Sales growth } & -0.0485 & 0.0329 & -0.0475 & 0.0528 \\
\hline & $(-0.49)$ & $(0.29)$ & $(-0.54)$ & $(0.52)$ \\
\hline \multirow[t]{2}{*}{ Annual return } & $0.1094 * * *$ & 0.0646 & $0.0945 * * *$ & 0.0411 \\
\hline & $(3.14)$ & $(1.59)$ & $(3.02)$ & (1.14) \\
\hline \multirow[t]{2}{*}{ Debt/equity ratio } & $0.1202 * * *$ & $0.2068 * * *$ & $0.0998 * * *$ & $0.1826 * * *$ \\
\hline & $(16.26)$ & $(23.93)$ & $(15.07)$ & $(23.94)$ \\
\hline \multirow[t]{2}{*}{ Cash surplus } & $-2.3257 * * *$ & $-3.3675 * * *$ & $-2.5119 * * *$ & $-3.4978 * * *$ \\
\hline & $(-8.49)$ & $(-10.54)$ & $(-10.24)$ & $(-12.38)$ \\
\hline \multirow[t]{2}{*}{ Intercept } & $-5.9502 * * *$ & $-6.5685 * * *$ & $-5.6198 * * *$ & $-6.3009 * * *$ \\
\hline & $(-20.99)$ & $(-20.08)$ & $(-21.88)$ & $(-21.54)$ \\
\hline $\mathrm{N}$ & 1,984 & 1,984 & 1,984 & 1,984 \\
\hline Adjusted R-squared & 0.56 & 0.52 & 0.61 & 0.56 \\
\hline
\end{tabular}


Table 5 Comparison between $k$ and $k^{*}$ as measure of CEO inside debt - 2SLS

This table presents the results of our 2SLS analysis for 2006-2010 in which the dependent variable is Log of total risk or Log of idiosyncratic risk and the independent variables of interest are two inside debt measures: CEO to firm debt/equity ratio (k) and adjusted CEO to firm debt/equity ratio ( $\left.\mathrm{k}^{*}\right)$. In Columns 12 , the dependent variable is measured in year $\mathrm{t}+1$. In Columns 3-4 the dependent variable is measured in years $\mathrm{t}+1$ through $\mathrm{t}+3$. We first regress $\mathrm{k}$ and $\mathrm{k} *$ on our instruments and then use the predicted values from the first-stage regression results as explanatory variables. In our first-stage regression we exclude CEO age because it is used to calculate $\mathrm{k}^{*}$. Variable calculation methodology and definitions are provided in Appendix A and Appendix B. Each model includes industry (two-digit SIC) and year fixed effects. $* * *, * *$, and * represent significance at the $1 \%, 5 \%$, and $10 \%$ levels, respectively.

\begin{tabular}{|c|c|c|c|c|c|c|c|c|}
\hline \multirow[b]{3}{*}{ Controls } & \multicolumn{2}{|l|}{$(1)$} & \multicolumn{2}{|l|}{$(2)$} & \multicolumn{2}{|l|}{$(3)$} & \multicolumn{2}{|l|}{ (4) } \\
\hline & \multicolumn{2}{|c|}{ Log of total risk $\mathrm{t}+1$} & \multicolumn{2}{|c|}{$\begin{array}{l}\text { Log of idiosyncratic risk } \\
t+1\end{array}$} & \multicolumn{2}{|c|}{ Log of total risk $t+3$} & \multicolumn{2}{|c|}{$\begin{array}{l}\text { Log of idiosyncratic risk } \\
t+3\end{array}$} \\
\hline & $\mathrm{k}^{*}$ & $\mathrm{k}$ & $\mathrm{k}^{*}$ & $\mathrm{k}$ & $\mathrm{k}^{*}$ & $\mathrm{k}$ & $\mathrm{k}^{*}$ & $\mathrm{k}$ \\
\hline Log of Adjusted CEO to firm debt/equity ratio & $\begin{array}{l}-0.1694 * * * \\
(-4.29)\end{array}$ & & $\begin{array}{l}-0.2548 * * * \\
(-5.37)\end{array}$ & & $\begin{array}{l}-0.2232 * * * \\
(-4.75)\end{array}$ & & $\begin{array}{l}-0.3008 * * * \\
(-5.36)\end{array}$ & \\
\hline Log of CEO to firm debt/equity ratio & & $\begin{array}{l}-0.1654 * * * \\
(-4.15)\end{array}$ & & $\begin{array}{l}-0.2507 * * * \\
(-5.23)\end{array}$ & & $\begin{array}{l}-0.2185^{* * * *} \\
(-4.62)\end{array}$ & & $\begin{array}{l}-0.2966^{* * * *} \\
(-5.25)\end{array}$ \\
\hline Annual return & $\begin{array}{l}0.1275 * * * \\
(3.63)\end{array}$ & $\begin{array}{l}0.1278 * * * \\
(3.66)\end{array}$ & $\begin{array}{l}0.1492 * * * \\
(3.54)\end{array}$ & $\begin{array}{l}0.1496 * * * \\
(3.57)\end{array}$ & $\begin{array}{l}0.0736^{*} \\
(1.76)\end{array}$ & $\begin{array}{l}0.0739 * \\
(1.78)\end{array}$ & $\begin{array}{l}0.1022 * * \\
(2.05)\end{array}$ & $\begin{array}{l}0.1026 * * \\
(2.07)\end{array}$ \\
\hline Cash surplus & $\begin{array}{l}-2.6922 * * * \\
(-9.99)\end{array}$ & $\begin{array}{l}-2.695 * * * \\
(-10.04)\end{array}$ & $\begin{array}{l}-2.4594 * * * \\
(-7.60)\end{array}$ & $\begin{array}{l}-2.4629 * * * \\
(-7.64)\end{array}$ & $\begin{array}{l}-3.6429 * * * \\
(-11.37)\end{array}$ & $\begin{array}{l}-3.6462 * * * \\
(-11.43)\end{array}$ & $\begin{array}{l}-3.4477 * * * \\
(-9.01)\end{array}$ & $\begin{array}{l}-3.4515^{* * * *} \\
(-9.06)\end{array}$ \\
\hline CEO vega/delta ratio & $\begin{array}{l}0.0008 \\
(1.23)\end{array}$ & $\begin{array}{l}0.0008 \\
(1.26)\end{array}$ & $\begin{array}{l}0.0007 \\
(0.94)\end{array}$ & $\begin{array}{l}0.0007 \\
(0.97)\end{array}$ & $\begin{array}{l}0.0012 * \\
(1.66)\end{array}$ & $\begin{array}{l}0.0012 * \\
(1.69)\end{array}$ & $\begin{array}{l}0.0013 \\
(1.51)\end{array}$ & $\begin{array}{l}0.0014 \\
(1.54)\end{array}$ \\
\hline Debt/equity ratio & $\begin{array}{l}0.1018 * * * \\
(13.94)\end{array}$ & $\begin{array}{l}0.102 * * * \\
(14.01)\end{array}$ & $\begin{array}{l}0.1218 * * * \\
(13.87)\end{array}$ & $\begin{array}{l}0.1219 * * * \\
(13.95)\end{array}$ & $\begin{array}{l}0.1844 * * * \\
(21.24)\end{array}$ & $\begin{array}{l}0.1846 * * * \\
(21.36)\end{array}$ & $\begin{array}{l}0.2087 * * * \\
(20.13)\end{array}$ & $\begin{array}{l}0.2089 * * * \\
(20.23)\end{array}$ \\
\hline Log of total current comp(salary+bonus) & $\begin{array}{l}-0.2241 * * * \\
(-6.59)\end{array}$ & $\begin{array}{l}-0.2263 * * * \\
(-6.68)\end{array}$ & $\begin{array}{l}-0.2729 * * * \\
(-6.68)\end{array}$ & $\begin{array}{l}-0.2762 * * * \\
(-6.79)\end{array}$ & $\begin{array}{l}-0.166^{* * * *} \\
(-4.11)\end{array}$ & $\begin{array}{l}-0.1689 * * * \\
(-4.20)\end{array}$ & $\begin{array}{l}-0.1888 * * * \\
(-3.91)\end{array}$ & $\begin{array}{l}-0.1926^{* * *} \\
(-4.01)\end{array}$ \\
\hline Market-to-book ratio & $\begin{array}{l}-0.0047 \\
(-1.33)\end{array}$ & $\begin{array}{l}-0.0047 \\
(-1.33)\end{array}$ & $\begin{array}{l}-0.0061 \\
(-1.43)\end{array}$ & $\begin{array}{l}-0.006 \\
(-1.43)\end{array}$ & $\begin{array}{l}-0.005 \\
(-1.20)\end{array}$ & $\begin{array}{l}-0.005 \\
(-1.20)\end{array}$ & $\begin{array}{l}-0.006 \\
(-1.19)\end{array}$ & $\begin{array}{l}-0.0059 \\
(-1.19)\end{array}$ \\
\hline Sales growth & $\begin{array}{l}-0.0275 \\
(-0.28)\end{array}$ & $\begin{array}{l}-0.0266 \\
(-0.27)\end{array}$ & $\begin{array}{l}-0.02 \\
(-0.17)\end{array}$ & $\begin{array}{l}-0.0189 \\
(-0.16)\end{array}$ & $\begin{array}{l}0.0768 \\
(0.65)\end{array}$ & $\begin{array}{l}0.0778 \\
(0.66)\end{array}$ & $\begin{array}{l}0.0649 \\
(0.46)\end{array}$ & $\begin{array}{l}0.0659 \\
(0.47)\end{array}$ \\
\hline $\mathrm{N}$ & 1,984 & 1,984 & 1,984 & 1,984 & 1,984 & 1,984 & 1,984 & 1,984 \\
\hline Adjusted R-squared & 0.55 & 0.55 & 0.47 & 0.47 & 0.49 & 0.49 & 0.43 & 0.44 \\
\hline
\end{tabular}




\begin{tabular}{|c|c|c|}
\hline $1^{\text {st }}$ stage results & (1) & $(2)$ \\
\hline Controls & $\mathrm{k}$ & $\mathrm{k}^{*}$ \\
\hline \multirow[t]{2}{*}{ Annual return } & $-0.18 * *$ & $-0.1792 * *$ \\
\hline & $(-2.43)$ & $(-2.42)$ \\
\hline \multirow[t]{2}{*}{ Cash surplus } & $5.5275^{* * *}$ & $5.5801 * * *$ \\
\hline & $(9.14)$ & $(9.21)$ \\
\hline \multirow[t]{2}{*}{ CEO vega/delta ratio } & $-0.0343 * * *$ & $-0.0344 * * *$ \\
\hline & $(-26.11)$ & $(-26.16)$ \\
\hline \multirow[t]{2}{*}{ Debt/equity ratio } & $-0.1411 * * *$ & $-0.1407 * * *$ \\
\hline & $(-8.99)$ & $(-8.95)$ \\
\hline \multirow[t]{2}{*}{ Liquidity constraint } & $0.3381 *$ & $0.3305^{*}$ \\
\hline & $(1.69)$ & $(1.65)$ \\
\hline \multirow[t]{2}{*}{ Log of firm age } & $0.2876^{* * *}$ & $0.2941 * * *$ \\
\hline & $(4.74)$ & $(4.83)$ \\
\hline \multirow[t]{2}{*}{ Log of total assets } & -0.0286 & -0.0221 \\
\hline & $(-0.81)$ & $(-0.62)$ \\
\hline \multirow[t]{2}{*}{ Log of total current comp(salary+bonus) } & -0.0371 & -0.0212 \\
\hline & $(-0.44)$ & $(-0.25)$ \\
\hline \multirow[t]{2}{*}{ Market-to-book ratio } & 0.0014 & 0.0015 \\
\hline & $(0.19)$ & $(0.20)$ \\
\hline \multirow[t]{2}{*}{ New CEO } & -0.0828 & -0.1082 \\
\hline & $(-0.78)$ & $(-1.02)$ \\
\hline \multirow[t]{2}{*}{ Sales growth } & -0.0112 & -0.0045 \\
\hline & $(-0.05)$ & $(-0.02)$ \\
\hline \multirow[t]{2}{*}{ State wage tax rate } & $3.2625 * * *$ & $3.1479 * * *$ \\
\hline & $(2.74)$ & $(2.64)$ \\
\hline \multirow[t]{2}{*}{ Tax status } & $-0.3009 * * *$ & $-0.3011 * * *$ \\
\hline & $(-4.02)$ & $(-4.01)$ \\
\hline $\mathrm{N}$ & 1,984 & 1,984 \\
\hline Adjusted R-squared & 0.44 & 0.44 \\
\hline
\end{tabular}




\section{Table 6 Investment versus Non-investment grade}

This table presents the OLS regression results in which the dependent variable is Log of total risk $t+1$, and the independent variables are the two inside debt measures: CEO to firm debt/equity ratio $(\mathrm{k})$ and adjusted CEO to firm debt/equity ratio $\left(\mathrm{k}^{*}\right)$. In this table, we split the sample into investment grade group (Baa3 or above, Moody's) in columns 1-2 and non-investment grade group (below Baa3, Moody's) in columns 3-4. Variable definitions are provided in Appendices A and B. Each model includes industry (two-digit SIC) and year fixed effects. ***, **, and * represent significance at the $1 \%$, $5 \%$, and $10 \%$ levels, respectively.

\begin{tabular}{|c|c|c|c|c|}
\hline \multirow[b]{4}{*}{ Controls } & $(1)$ & $(2)$ & (3) & $(4)$ \\
\hline & \multicolumn{2}{|c|}{ Investment grade } & \multicolumn{2}{|c|}{ Non-investment grade } \\
\hline & \multicolumn{2}{|c|}{ Log of total risk $t+1$} & \multicolumn{2}{|c|}{ Log of total risk $\mathrm{t}+1$} \\
\hline & $\mathrm{k}^{*}$ & $\mathrm{k}$ & $\mathrm{k}^{*}$ & $\mathrm{k}$ \\
\hline Log of Adjusted CEO to firm debt/equity ratio & $\begin{array}{l}-0.0425 * * * \\
(-2.70)\end{array}$ & & $\begin{array}{l}-0.0477 * * \\
(-2.19)\end{array}$ & \\
\hline Log of CEO to firm debt/equity ratio & & $\begin{array}{l}-0.0425^{* * *} \\
(-2.71)\end{array}$ & & $\begin{array}{l}-0.0460 * * \\
(-2.10)\end{array}$ \\
\hline Annual return & $\begin{array}{l}0.0946^{* *} \\
(2.56)\end{array}$ & $\begin{array}{l}0.0946 * * \\
(2.55)\end{array}$ & $\begin{array}{l}0.0031 \\
(0.04)\end{array}$ & $\begin{array}{l}0.003 \\
(0.04)\end{array}$ \\
\hline Cash surplus & $\begin{array}{l}-2.046 * * * \\
(-5.64)\end{array}$ & $\begin{array}{l}-2.0467 * * * \\
(-5.64)\end{array}$ & $\begin{array}{l}-2.488 * * * \\
(-5.03)\end{array}$ & $\begin{array}{l}-2.4923 * * * \\
(-5.05)\end{array}$ \\
\hline CEO vega/delta ratio & $\begin{array}{l}-0.001 \\
(-1.31)\end{array}$ & $\begin{array}{l}-0.001 \\
(-1.31)\end{array}$ & $\begin{array}{l}0.0019 \\
(1.35)\end{array}$ & $\begin{array}{l}0.002 \\
(1.44)\end{array}$ \\
\hline Debt/equity ratio & $\begin{array}{l}0.1041 * * * \\
(9.89)\end{array}$ & $\begin{array}{l}0.1041^{* * * *} \\
(9.88)\end{array}$ & $\begin{array}{l}0.1267 * * * \\
(6.47)\end{array}$ & $\begin{array}{l}0.127 * * * \\
(6.46)\end{array}$ \\
\hline Log of firm age & $\begin{array}{l}-0.1888^{* * * *} \\
(-4.05)\end{array}$ & $\begin{array}{l}-0.1889 * * * \\
(-4.06)\end{array}$ & $\begin{array}{l}-6.0234 * * * \\
(-11.92)\end{array}$ & $\begin{array}{l}-6.007 * * * \\
(-11.89)\end{array}$ \\
\hline Log of total assets & $\begin{array}{l}-0.1574 * * * \\
(-6.57)\end{array}$ & $\begin{array}{l}-0.1574 * * * \\
(-6.57)\end{array}$ & $\begin{array}{l}-0.1763^{* *} \\
(-2.59)\end{array}$ & $\begin{array}{l}-0.1766^{* *} \\
(-2.59)\end{array}$ \\
\hline Log of total current comp(salary+bonus) & $\begin{array}{l}0.099^{*} \\
(1.85)\end{array}$ & $\begin{array}{l}0.0987^{*} \\
(1.85)\end{array}$ & $\begin{array}{l}-0.0914 * * * \\
(-2.67)\end{array}$ & $\begin{array}{l}-0.0905 * * * \\
(-2.65)\end{array}$ \\
\hline Market-to-book ratio & $\begin{array}{l}-0.0072 * * \\
(-2.23)\end{array}$ & $\begin{array}{l}-0.0072 * * \\
(-2.23)\end{array}$ & $\begin{array}{l}-0.0009 \\
(-0.01)\end{array}$ & $\begin{array}{l}-0.0034 \\
(-0.05)\end{array}$ \\
\hline Sales growth & $\begin{array}{l}0.001 \\
(0.01)\end{array}$ & $\begin{array}{l}0.0012 \\
(0.01)\end{array}$ & $\begin{array}{l}0.0064 \\
(1.43)\end{array}$ & $\begin{array}{l}0.0065 \\
(1.43)\end{array}$ \\
\hline Intercept & $\begin{array}{l}-6.2467 * * * \\
(-17.08)\end{array}$ & $\begin{array}{l}-6.243 * * * \\
(-17.08)\end{array}$ & $\begin{array}{l}-0.0877 \\
(-0.56)\end{array}$ & $\begin{array}{l}-0.0896 \\
(-0.58)\end{array}$ \\
\hline $\mathrm{N}$ & 1,528 & 1,528 & 456 & 456 \\
\hline Adjusted R-squared & 0.51 & 0.51 & 0.69 & 0.69 \\
\hline
\end{tabular}




\section{Table 7 Downgrades}

This table reports OLS analysis for 410 firms that experienced a credit rating downgrade (of one or more "notches"). The dependent variables are Log of idiosyncratic risk $t+1, \log$ of idiosyncratic risk $\mathrm{t}+3, \log$ of total risk $\mathrm{t}+1$, Log of total risk $\mathrm{t}+3$, and the principal independent variables are the two inside debt measures: CEO to firm debt/equity ratio (k) and adjusted $\mathrm{CEO}$ to firm debt/equity ratio ( $\mathrm{k}^{*}$ ). Variable definitions are provided in Appendices A and B. Each model includes industry (two-digit SIC) and year fixed effects. $* * *, * *$, and $*$ represent significance at the $1 \%, 5 \%$, and $10 \%$ levels, respectively.

\begin{tabular}{|c|c|c|c|c|c|c|c|c|}
\hline & $(1)$ & $(2)$ & $(3)$ & (4) & $(5)$ & $(6)$ & $(7)$ & $(8)$ \\
\hline & \multicolumn{2}{|c|}{ Log of idiosyncratic risk $t+1$} & \multicolumn{2}{|c|}{ Log of idiosyncratic risk $\mathrm{t}+3$} & \multicolumn{2}{|c|}{ Log of total risk $\mathrm{t}+1$} & \multicolumn{2}{|c|}{ Log of total risk $t+3$} \\
\hline & $\mathrm{k}^{*}$ & $\mathrm{k}$ & $\mathrm{k}^{*}$ & $\mathrm{k}$ & $\mathrm{k}^{*}$ & $\mathrm{k}$ & $\mathrm{k}^{*}$ & $\mathrm{k}$ \\
\hline $\begin{array}{l}\text { Log of Adjusted CEO } \\
\text { to firm debt/Equity ratio }\end{array}$ & $\begin{array}{l}-0.0774 * * \\
(-2.54)\end{array}$ & & $\begin{array}{l}-0.0488 \\
(-1.16)\end{array}$ & & $\begin{array}{l}-0.0764 * * * \\
(-3.04)\end{array}$ & & $\begin{array}{l}-0.0529 \\
(-1.44)\end{array}$ & \\
\hline $\begin{array}{l}\text { Log of CEO to firm } \\
\text { debt/Equity ratio }\end{array}$ & & $\begin{array}{l}-0.0754 * * \\
(-2.47)\end{array}$ & & $\begin{array}{l}-0.0484 \\
(-1.15)\end{array}$ & & $\begin{array}{l}-0.0741 * * * \\
(-2.96)\end{array}$ & & $\begin{array}{l}-0.0525 \\
(-1.43)\end{array}$ \\
\hline Annual Return & $\begin{array}{l}0.1439 * * \\
(2.10)\end{array}$ & $\begin{array}{l}0.1447 * * \\
(2.11)\end{array}$ & $\begin{array}{l}0.0609 \\
(0.86)\end{array}$ & $\begin{array}{l}0.0611 \\
(0.86)\end{array}$ & $\begin{array}{l}0.1241^{* *} \\
(1.98)\end{array}$ & $\begin{array}{l}0.1249 * * \\
(1.99)\end{array}$ & $\begin{array}{l}0.04 \\
(0.61)\end{array}$ & $\begin{array}{l}0.0403 \\
(0.61)\end{array}$ \\
\hline Cash surplus & $\begin{array}{l}-2.2184 * * * \\
(-3.53)\end{array}$ & $\begin{array}{l}-2.2328 * * * \\
(-3.56)\end{array}$ & $\begin{array}{l}-3.0774 * * * \\
(-2.95)\end{array}$ & $\begin{array}{l}-3.0824 * * * \\
(-2.96)\end{array}$ & $\begin{array}{l}-2.4262 * * * \\
(-4.58)\end{array}$ & $\begin{array}{l}-2.4402 * * * \\
(-4.61)\end{array}$ & $\begin{array}{l}-3.2086 * * * \\
(-3.39)\end{array}$ & $\begin{array}{l}-3.2142 * * * \\
(-3.40)\end{array}$ \\
\hline CEO Vega/Delta Ratio & $\begin{array}{l}-0.0006 \\
(-0.40)\end{array}$ & $\begin{array}{l}-0.0005 \\
(-0.35)\end{array}$ & $\begin{array}{l}0.0049 \\
(1.18)\end{array}$ & $\begin{array}{l}0.0049 \\
(1.19)\end{array}$ & $\begin{array}{l}-0.0006 \\
(-0.47)\end{array}$ & $\begin{array}{l}-0.0005 \\
(-0.40)\end{array}$ & $\begin{array}{l}0.0041 \\
(1.24)\end{array}$ & $\begin{array}{l}0.0041 \\
(1.26)\end{array}$ \\
\hline Debt/Equity ratio & $\begin{array}{l}0.123 * * * \\
(12.00)\end{array}$ & $\begin{array}{l}0.1233 * * * \\
(12.01)\end{array}$ & $\begin{array}{l}0.229 * * * \\
(7.70)\end{array}$ & $\begin{array}{l}0.2291 * * * \\
(7.70)\end{array}$ & $\begin{array}{l}0.1018 * * * \\
(11.07)\end{array}$ & $\begin{array}{l}0.102 * * * \\
(11.08)\end{array}$ & $\begin{array}{l}0.2033 * * * \\
(6.81)\end{array}$ & $\begin{array}{l}0.2034 * * * \\
(6.82)\end{array}$ \\
\hline Intercept & $\begin{array}{l}-7.2077 * * * \\
(-10.69)\end{array}$ & $\begin{array}{l}-7.1729 * * * \\
(-10.57)\end{array}$ & $\begin{array}{l}-7.7588 * * * \\
(-9.15)\end{array}$ & $\begin{array}{l}-7.7385^{* * *} \\
(-9.09)\end{array}$ & $\begin{array}{l}-6.4101 * * * \\
(-10.95)\end{array}$ & $\begin{array}{l}-6.376^{* * *} \\
(-10.84)\end{array}$ & $\begin{array}{l}-7.0521 * * * \\
(-9.20)\end{array}$ & $\begin{array}{l}-7.03 * * * \\
(-9.15)\end{array}$ \\
\hline Log of firm age & $\begin{array}{l}-0.0935 \\
(-0.88)\end{array}$ & $\begin{array}{l}-0.0954 \\
(-0.89)\end{array}$ & $\begin{array}{l}-0.1414 \\
(-1.13)\end{array}$ & $\begin{array}{l}-0.1423 \\
(-1.14)\end{array}$ & $\begin{array}{l}-0.0393 \\
(-0.47)\end{array}$ & $\begin{array}{l}-0.0412 \\
(-0.49)\end{array}$ & $\begin{array}{l}-0.0844 \\
(-0.82)\end{array}$ & $\begin{array}{l}-0.0854 \\
(-0.83)\end{array}$ \\
\hline Log of total assets & $\begin{array}{l}-0.107 * * * \\
(-2.66)\end{array}$ & $\begin{array}{l}-0.1069 * * * \\
(-2.66)\end{array}$ & $\begin{array}{l}-0.1381 * * * \\
(-3.13)\end{array}$ & $\begin{array}{l}-0.1381 * * * \\
(-3.13)\end{array}$ & $\begin{array}{l}-0.0967 * * * \\
(-2.75)\end{array}$ & $\begin{array}{l}-0.0966 * * * \\
(-2.75)\end{array}$ & $\begin{array}{l}-0.1311 * * * \\
(-3.41)\end{array}$ & $\begin{array}{l}-0.131 * * * \\
(-3.41)\end{array}$ \\
\hline Log of total current comp(salary+bonus) & $\begin{array}{l}-0.0217 \\
(-0.26)\end{array}$ & $\begin{array}{l}-0.0247 \\
(-0.30)\end{array}$ & $\begin{array}{l}0.0216 \\
(0.22)\end{array}$ & $\begin{array}{l}0.0197 \\
(0.20)\end{array}$ & $\begin{array}{l}-0.039 \\
(-0.49)\end{array}$ & $\begin{array}{l}-0.0419 \\
(-0.53)\end{array}$ & $\begin{array}{l}-0.0077 \\
(-0.08)\end{array}$ & $\begin{array}{l}-0.0098 \\
(-0.11)\end{array}$ \\
\hline Market-to-book ratio & $\begin{array}{l}0.0067 \\
(1.27)\end{array}$ & $\begin{array}{l}0.0068 \\
(1.28)\end{array}$ & $\begin{array}{l}0.0189 \\
(1.49)\end{array}$ & $\begin{array}{l}0.019 \\
(1.50)\end{array}$ & $\begin{array}{l}0.0048 \\
(0.73)\end{array}$ & $\begin{array}{l}0.0048 \\
(0.74)\end{array}$ & $\begin{array}{l}0.0114 \\
(0.89)\end{array}$ & $\begin{array}{l}0.0114 \\
(0.90)\end{array}$ \\
\hline Sales Growth & 0.0055 & 0.0014 & 0.5505 & 0.5476 & 0.0352 & 0.0311 & 0.5467 & 0.5436 \\
\hline
\end{tabular}




\begin{tabular}{|c|c|c|c|c|c|c|c|c|}
\hline & $(0.02)$ & $(0.01)$ & (1.03) & (1.03) & $(0.17)$ & $(0.15)$ & (1.12) & (1.11) \\
\hline $\mathrm{N}$ & 410 & 410 & 410 & 410 & 410 & 410 & 410 & 410 \\
\hline Adjusted R-squared & 0.7 & 0.69 & 0.65 & 0.65 & 0.7 & 0.7 & 0.67 & 0.67 \\
\hline
\end{tabular}




\section{Table 8 Above versus Below Median 1-DP*(1-RR)}

This table presents OLS regression results in which the dependent variable is the Log of total risk or Log of idiosyncratic risk and the independent variables are our inside debt measures: CEO to firm debt/equity ratio (k) and adjusted CEO to firm debt/equity ratio ( $\left.\mathrm{k}^{*}\right)$. We split the sample into two subsamples: above median 1-DP*(1-RR) in Panel A and below median 1-DP*(1-RR) in Panel B. Variable calculation methodology and definitions are provided in Appendices A and B. Each model includes industry (two-digit SIC) and year fixed effects. ***, **, and * represent significance at the $1 \%, 5 \%$, and $10 \%$ levels, respectively.

\begin{tabular}{|c|c|c|c|c|c|c|c|c|}
\hline \multirow[t]{3}{*}{ Panel A Above Median Subsample (Safe Firms) } & $(1)$ & $(2)$ & $(3)$ & $(4)$ & $(5)$ & $(6)$ & $(7)$ & $(8)$ \\
\hline & \multicolumn{2}{|c|}{ Log of idiosyncratic risk $t+1$} & \multicolumn{2}{|c|}{ Log of idiosyncratic risk $t+3$} & \multicolumn{2}{|c|}{ Log of total risk $\mathrm{t}+1$} & \multicolumn{2}{|c|}{ Log of total risk $\mathrm{t}+3$} \\
\hline & $\mathrm{k}^{*}$ & $\mathrm{k}$ & $\mathrm{k}^{*}$ & $\mathrm{k}$ & $\mathrm{k}^{*}$ & $\mathrm{k}$ & $\mathrm{k}^{*}$ & $\mathrm{k}$ \\
\hline \multirow[t]{2}{*}{ Log of Adjusted CEO to firm debt/equity ratio } & $-0.0422 * *$ & & -0.0311 & & $-0.0431 * *$ & & $-0.0352 *$ & \\
\hline & $(-2.26)$ & & $(-1.28)$ & & $(-2.57)$ & & $(-1.68)$ & \\
\hline \multirow[t]{2}{*}{ Log of CEO to firm debt/equity ratio } & & $-0.0421 * *$ & & -0.0312 & & $-0.0431 * *$ & & $-0.0352 *$ \\
\hline & & $(-2.26)$ & & $(-1.28)$ & & $(-2.58)$ & & $(-1.68)$ \\
\hline \multirow[t]{2}{*}{ Annual return } & 0.0965 & 0.0966 & 0.0081 & 0.0081 & 0.0743 & 0.0744 & -0.0025 & -0.0024 \\
\hline & $(1.59)$ & $(1.59)$ & $(0.11)$ & $(0.11)$ & $(1.34)$ & $(1.35)$ & $(-0.04)$ & $(-0.04)$ \\
\hline \multirow[t]{2}{*}{ Cash surplus } & $-2.0458 * * *$ & $-2.0474 * * *$ & $-3.9605 * * *$ & $-3.9611 * * *$ & $-2.2594 * * *$ & $-2.2606 * * *$ & $-4.103 * * *$ & $-4.1035^{* * *}$ \\
\hline & $(-4.02)$ & $(-4.03)$ & $(-5.84)$ & $(-5.85)$ & $(-5.29)$ & $(-5.29)$ & $(-6.03)$ & $(-6.03)$ \\
\hline \multirow[t]{2}{*}{ CEO vega/delta ratio } & -0.0008 & -0.0008 & 0.0011 & 0.0011 & -0.0008 & -0.0008 & 0.0007 & 0.0007 \\
\hline & $(-0.77)$ & $(-0.76)$ & $(0.52)$ & $(0.52)$ & $(-0.94)$ & $(-0.94)$ & $(0.37)$ & $(0.37)$ \\
\hline \multirow[t]{2}{*}{ Debt/equity ratio } & $0.1127 * * *$ & $0.1127 * * *$ & $0.1975^{* * *}$ & $0.1975 * * *$ & $0.0902 * * *$ & $0.0902 * * *$ & $0.1729 * * *$ & $0.1728 * * *$ \\
\hline & $(7.80)$ & $(7.80)$ & $(4.72)$ & $(4.72)$ & $(7.11)$ & $(7.11)$ & $(4.38)$ & $(4.38)$ \\
\hline \multirow[t]{2}{*}{ Log of firm age } & $-0.1275^{* *}$ & $-0.1277 * *$ & $-0.1564 * *$ & $-0.1565^{* *}$ & -0.0486 & -0.0487 & -0.071 & -0.0711 \\
\hline & $(-2.21)$ & $(-2.21)$ & $(-2.21)$ & $(-2.21)$ & $(-0.94)$ & $(-0.94)$ & $(-1.16)$ & $(-1.16)$ \\
\hline \multirow[t]{2}{*}{ Log of total assets } & $-0.1262 * * *$ & $-0.1262 * * *$ & $-0.1296 * * *$ & $-0.1296 * * *$ & $-0.128 * * *$ & $-0.128 * * *$ & $-0.1399 * * *$ & $-0.1399 * * *$ \\
\hline & $(-4.24)$ & $(-4.24)$ & $(-3.28)$ & $(-3.28)$ & $(-4.74)$ & $(-4.74)$ & $(-4.01)$ & $(-4.01)$ \\
\hline \multirow[t]{2}{*}{ Log of total current comp(salary+bonus) } & $-0.1242 * *$ & $-0.1244 * *$ & 0.0133 & 0.0131 & -0.0845 & -0.0847 & 0.0358 & 0.0356 \\
\hline & $(-2.03)$ & $(-2.03)$ & $(0.14)$ & $(0.14)$ & $(-1.47)$ & $(-1.47)$ & $(0.45)$ & $(0.45)$ \\
\hline \multirow[t]{2}{*}{ Market-to-book ratio } & $-0.0072 *$ & $-0.0072 *$ & $-0.0089 * *$ & $-0.0089 * *$ & $-0.0067 *$ & $-0.0067 *$ & $-0.0071 * *$ & $-0.0071 * *$ \\
\hline & $(-1.69)$ & $(-1.69)$ & $(-2.57)$ & $(-2.57)$ & $(-1.75)$ & $(-1.75)$ & $(-2.27)$ & $(-2.27)$ \\
\hline \multirow[t]{2}{*}{ Sales growth } & -0.0298 & -0.0297 & -0.1369 & -0.1369 & 0.0675 & 0.0676 & -0.036 & -0.036 \\
\hline & $(-0.16)$ & $(-0.16)$ & $(-0.62)$ & $(-0.62)$ & $(0.44)$ & $(0.44)$ & $(-0.20)$ & $(-0.20)$ \\
\hline \multirow[t]{2}{*}{ Intercept } & $-5.3257 * * *$ & $-5.3215 * * *$ & $-6.908 * * *$ & $-6.905^{* * *}$ & $-5.3817 * * *$ & $-5.3774 * * *$ & $-6.9128 * * *$ & $-6.9093 * * *$ \\
\hline & $(-10.85)$ & $(-10.85)$ & $(-9.04)$ & $(-9.04)$ & $(-11.80)$ & $(-11.80)$ & $(-10.63)$ & $(-10.63)$ \\
\hline
\end{tabular}




\begin{tabular}{|c|c|c|c|c|c|c|c|c|}
\hline $\mathrm{N}$ & 1,099 & 1,099 & 1,099 & 1,099 & 1,099 & 1,099 & 1,099 & 1,099 \\
\hline Adjusted R-squared & 0.54 & 0.54 & 0.51 & 0.51 & 0.60 & 0.60 & 0.55 & 0.55 \\
\hline \multirow[t]{3}{*}{ Panel B Below Median Subsample (Risky firms) } & $(1)$ & $(2)$ & $(3)$ & $(4)$ & $(5)$ & $(6)$ & $(7)$ & $(8)$ \\
\hline & \multicolumn{2}{|c|}{ Log of idiosyncratic risk $t+1$} & \multicolumn{2}{|c|}{ Log of idiosyncratic risk $t+3$} & \multicolumn{2}{|c|}{ Log of total risk $\mathrm{t}+1$} & \multicolumn{2}{|c|}{ Log of total risk $\mathrm{t}+3$} \\
\hline & $\mathrm{k}^{*}$ & $\mathrm{k}$ & $\mathrm{k}^{*}$ & $\mathrm{k}$ & $\mathrm{k}^{*}$ & $\mathrm{k}$ & $\mathrm{k}^{*}$ & $\mathrm{k}$ \\
\hline Log of Adjusted CEO to firm debt/equity ratio & $\begin{array}{l}-0.0702 * * * \\
(-3.34)\end{array}$ & & $\begin{array}{l}-0.0557^{*} \\
(-1.94)\end{array}$ & & $\begin{array}{l}-0.0626^{* * *} \\
(-3.25)\end{array}$ & & $\begin{array}{l}-0.0532 * * \\
(-2.02)\end{array}$ & \\
\hline Log of CEO to firm debt/equity ratio & & $\begin{array}{l}-0.069 * * * \\
(-3.29)\end{array}$ & & $\begin{array}{l}-0.0554^{*} \\
(-1.91)\end{array}$ & & $\begin{array}{l}-0.0616 \text { *** } \\
(-3.21)\end{array}$ & & $\begin{array}{l}-0.0527 * * \\
(-1.98)\end{array}$ \\
\hline Annual return & $\begin{array}{l}0.1036^{* * * *} \\
(2.83)\end{array}$ & $\begin{array}{l}0.1036^{* * * *} \\
(2.83)\end{array}$ & $\begin{array}{l}0.0779 * \\
(1.73)\end{array}$ & $\begin{array}{l}0.0778 * \\
(1.72)\end{array}$ & $\begin{array}{l}0.0953 * * * \\
(3.05)\end{array}$ & $\begin{array}{l}0.0953 * * * \\
(3.05)\end{array}$ & $\begin{array}{l}0.0572 \\
(1.36)\end{array}$ & $\begin{array}{l}0.0571 \\
(1.35)\end{array}$ \\
\hline Cash surplus & $\begin{array}{l}-2.2067 * * * \\
(-3.87)\end{array}$ & $\begin{array}{l}-2.2102 * * * \\
(-3.88)\end{array}$ & $\begin{array}{l}-2.3501 * * * \\
(-3.07)\end{array}$ & $\begin{array}{l}-2.3509 * * * \\
(-3.07)\end{array}$ & $\begin{array}{l}-2.405^{* * *} \\
(-5.22)\end{array}$ & $\begin{array}{l}-2.4081 \text { *** } \\
(-5.23)\end{array}$ & $\begin{array}{l}-2.5396 * * * \\
(-3.98)\end{array}$ & $\begin{array}{l}-2.541 * * * \\
(-3.98)\end{array}$ \\
\hline CEO vega/delta ratio & $\begin{array}{l}-0.0015 \\
(-1.59)\end{array}$ & $\begin{array}{l}-0.0014 \\
(-1.54)\end{array}$ & $\begin{array}{l}-0.0012 \\
(-1.03)\end{array}$ & -0.0012 & $\begin{array}{l}-0.0012 \\
(-1.35)\end{array}$ & $\begin{array}{l}-0.0011 \\
(-1.29)\end{array}$ & $\begin{array}{l}-0.0011 \\
(-0.98)\end{array}$ & $\begin{array}{l}-0.0011 \\
(-0.95)\end{array}$ \\
\hline Debt/equity ratio & $\begin{array}{l}0.1357 * * * \\
(6.76)\end{array}$ & $\begin{array}{l}0.136 * * * \\
(6.77)\end{array}$ & $\begin{array}{l}0.2277 * * * \\
(8.29)\end{array}$ & $\begin{array}{l}0.2278^{* * * *} \\
(8.30)\end{array}$ & $\begin{array}{l}0.1174 * * * \\
(6.66)\end{array}$ & $\begin{array}{l}0.1176^{* * * *} \\
(6.67)\end{array}$ & $\begin{array}{l}0.2039 * * * \\
(7.78)\end{array}$ & $\begin{array}{l}0.2041^{* * *} \\
(7.80)\end{array}$ \\
\hline Log of firm age & $\begin{array}{l}-0.1647 * * \\
(-2.21)\end{array}$ & $\begin{array}{l}-0.1648^{* *} \\
(-2.21)\end{array}$ & $\begin{array}{l}-0.1934^{* *} \\
(-2.32)\end{array}$ & $\begin{array}{l}-0.1934 * * \\
(-2.32)\end{array}$ & $\begin{array}{l}-0.1428^{* *} \\
(-2.42)\end{array}$ & $\begin{array}{l}-0.1429 * * \\
(-2.42)\end{array}$ & $\begin{array}{l}-0.1654 * * \\
(-2.43)\end{array}$ & $\begin{array}{l}-0.1654 * * \\
(-2.43)\end{array}$ \\
\hline Log of total assets & $\begin{array}{l}-0.1122^{* * * *} \\
(-3.34)\end{array}$ & $\begin{array}{l}-0.1119 * * * \\
(-3.33)\end{array}$ & $\begin{array}{l}-0.1069 * * * \\
(-3.20)\end{array}$ & $\begin{array}{l}-0.1068 * * * \\
(-3.20)\end{array}$ & $\begin{array}{l}-0.0999 * * * \\
(-3.28)\end{array}$ & $\begin{array}{l}-0.0997 * * * \\
(-3.27)\end{array}$ & $\begin{array}{l}-0.102 * * * \\
(-3.48)\end{array}$ & $\begin{array}{l}-0.1018^{* * *} \\
(-3.47)\end{array}$ \\
\hline Log of total current comp(salary+bonus) & $\begin{array}{l}-0.0068 \\
(-0.11)\end{array}$ & $\begin{array}{l}-0.0097 \\
(-0.16)\end{array}$ & $\begin{array}{l}-0.0114 \\
(-0.18)\end{array}$ & $\begin{array}{l}-0.0136 \\
(-0.22)\end{array}$ & $\begin{array}{l}-0.0012 \\
(-0.02)\end{array}$ & $\begin{array}{l}-0.0038 \\
(-0.06)\end{array}$ & $\begin{array}{l}-0.0122 \\
(-0.20)\end{array}$ & $\begin{array}{l}-0.0143 \\
(-0.24)\end{array}$ \\
\hline Market-to-book ratio & $\begin{array}{l}-0.002 \\
(-0.51)\end{array}$ & $\begin{array}{l}-0.002 \\
(-0.50)\end{array}$ & $\begin{array}{l}0.0043 \\
(0.62)\end{array}$ & $\begin{array}{l}0.0043 \\
(0.62)\end{array}$ & $\begin{array}{l}-0.0005 \\
(-0.12)\end{array}$ & $\begin{array}{l}-0.0005 \\
(-0.12)\end{array}$ & $\begin{array}{l}0.0029 \\
(0.43)\end{array}$ & $\begin{array}{l}0.0029 \\
(0.43)\end{array}$ \\
\hline Sales growth & $\begin{array}{l}-0.0243 \\
(-0.18)\end{array}$ & $\begin{array}{l}-0.026 \\
(-0.20)\end{array}$ & $\begin{array}{l}0.2481 \\
(1.05)\end{array}$ & $\begin{array}{l}0.2468 \\
(1.05)\end{array}$ & $\begin{array}{l}-0.1066 \\
(-0.94)\end{array}$ & $\begin{array}{l}-0.1081 \\
(-0.96)\end{array}$ & $\begin{array}{l}0.1904 \\
(0.88)\end{array}$ & $\begin{array}{l}0.1891 \\
(0.87)\end{array}$ \\
\hline Intercept & $\begin{array}{l}-6.7648 * * * \\
(-14.46)\end{array}$ & $\begin{array}{l}-6.7402 * * * \\
(-14.41)\end{array}$ & $\begin{array}{l}-6.9453 * * * \\
(-14.18)\end{array}$ & $\begin{array}{l}-6.9262 * * * \\
(-14.10)\end{array}$ & $\begin{array}{l}-5.9804 * * * \\
(-14.17)\end{array}$ & $\begin{array}{l}-5.9584 * * * \\
(-14.13)\end{array}$ & $\begin{array}{l}-6.2376^{* * * *} \\
(-14.38)\end{array}$ & $\begin{array}{l}-6.2193 * * * \\
(-14.29)\end{array}$ \\
\hline $\mathrm{N}$ & 885 & 885 & 885 & 885 & 885 & 885 & 885 & 885 \\
\hline Adjusted R-squared & 0.61 & 0.61 & 0.57 & 0.57 & 0.64 & 0.64 & 0.60 & 0.60 \\
\hline
\end{tabular}


Table 9 Credit Crisis Test - 2SLS

This table presents the results of our 2SLS regression analysis for 2006-2010, in which the dependent variable is Log of total risk $t+1$ or Log of idiosyncratic risk $\mathrm{t}+1$ and the independent variables of interest are two inside debt measures: CEO to firm debt/equity ratio $(\mathrm{k})$ and adjusted CEO to firm debt/equity ratio $(\mathrm{k} *)$. We separate our sample into two sub-periods, the crisis period (2007 and 2008) in Columns 1-4 and the non-crisis period (2006, 2009 and 2010) in Columns 5-8. We first regress $\mathrm{k}$ and $\mathrm{k}^{*}$ on our instruments and then use the predicted values from the first-stage regression as explanatory variables in the second stage. In the first stage we exclude CEO age because it is used to calculate $\mathrm{k}^{*}$. Variable calculation methodology and definitions are provided in Appendices A and B. Each model includes industry (two-digit SIC) and year fixed effects. ***,**, and * represent significance at the $1 \%, 5 \%$, and $10 \%$ levels, respectively.

\begin{tabular}{|c|c|c|c|c|c|c|c|c|}
\hline $2^{\text {nd }}$ stage results & (1) & $(2)$ & (3) & $(4)$ & $(5)$ & (6) & (7) & (8) \\
\hline & \multicolumn{4}{|l|}{ Crisis Period } & \multicolumn{4}{|c|}{ Non-crisis Period } \\
\hline & \multicolumn{2}{|c|}{ Log of idiosyncratic risk $t+1$} & \multicolumn{2}{|c|}{$\log$ of total risk $\mathrm{t}+1$} & \multicolumn{2}{|c|}{ Log of idiosyncratic risk $t+1$} & \multicolumn{2}{|c|}{$\log$ of total risk $t+1$} \\
\hline Controls & $\mathrm{k}^{*}$ & $\mathrm{k}$ & $\mathrm{k}^{*}$ & $\mathrm{k}$ & $\mathrm{k}^{*}$ & $\mathrm{k}$ & $\mathrm{k}^{*}$ & $\mathrm{k}$ \\
\hline $\begin{array}{l}\text { Log of Adjusted CEO to } \\
\text { firm debt/equity ratio }\end{array}$ & $\begin{array}{l}-0.2497 * * * \\
(-3.80)\end{array}$ & & $\begin{array}{l}-0.1879 * * * \\
(-3.30)\end{array}$ & & $\begin{array}{l}-0.2622 * * * \\
(-3.73)\end{array}$ & & $\begin{array}{l}-0.1355^{* *} \\
(-2.58)\end{array}$ & \\
\hline Log of CEO to firm debt/equity rati & & $\begin{array}{l}-0.2472 * * * \\
(-3.74)\end{array}$ & & $\begin{array}{l}-0.1861 * * * \\
(-3.24)\end{array}$ & & $\begin{array}{l}-0.2559 * * * \\
(-3.59)\end{array}$ & & $\begin{array}{l}-0.1282 * * \\
(-2.41)\end{array}$ \\
\hline Annual return & $\begin{array}{l}-0.2635^{* *} \\
(-2.52)\end{array}$ & $\begin{array}{l}-0.2633^{* *} \\
(-2.52)\end{array}$ & $\begin{array}{l}-0.3607 * * * \\
(-3.98)\end{array}$ & $\begin{array}{l}-0.3606 * * * \\
(-3.98)\end{array}$ & $\begin{array}{l}0.2547 * * * \\
(5.57)\end{array}$ & $\begin{array}{l}0.2552^{* * * *} \\
(5.63)\end{array}$ & $\begin{array}{l}0.2666^{* * * *} \\
(7.80)\end{array}$ & $\begin{array}{l}0.2671 * * * \\
(7.87)\end{array}$ \\
\hline Cash surplus & $\begin{array}{l}-3.315^{* * *} \\
(-6.43)\end{array}$ & $\begin{array}{l}-3.314 * * * \\
(-6.44)\end{array}$ & $\begin{array}{l}-3.3346^{* * *} \\
(-7.46)\end{array}$ & $\begin{array}{l}-3.3338 * * * \\
(-7.47)\end{array}$ & $\begin{array}{l}-1.2068 * * * \\
(-2.71)\end{array}$ & $\begin{array}{l}-1.215^{* * *} \\
(-2.75)\end{array}$ & $\begin{array}{l}-1.7011^{* * *} \\
(-5.11)\end{array}$ & $\begin{array}{l}-1.7064 * * * \\
(-5.17)\end{array}$ \\
\hline CEO vega/delta ratio & $\begin{array}{l}-0.0007 \\
(-0.65)\end{array}$ & $\begin{array}{l}-0.0007 \\
(-0.64)\end{array}$ & $\begin{array}{l}-0.0005 \\
(-0.54)\end{array}$ & $\begin{array}{l}-0.0005 \\
(-0.53)\end{array}$ & $\begin{array}{l}0.0025^{* *} \\
(2.28)\end{array}$ & $\begin{array}{l}0.0025^{* *} \\
(2.32)\end{array}$ & $\begin{array}{l}0.0022 * * * \\
(2.77)\end{array}$ & $\begin{array}{l}0.0023^{* * *} \\
(2.81)\end{array}$ \\
\hline Debt/equity ratio & $\begin{array}{l}0.0999^{* * *} \\
(10.13)\end{array}$ & $\begin{array}{l}0.0999 * * * \\
(10.15)\end{array}$ & $\begin{array}{l}0.0797 * * * * \\
(9.32)\end{array}$ & $\begin{array}{l}0.0797 * * * \\
(9.34)\end{array}$ & $\begin{array}{l}0.3509^{* * *} \\
(8.00)\end{array}$ & $\begin{array}{l}0.351^{* * * *} \\
(8.08)\end{array}$ & $\begin{array}{l}0.2749 * * * \\
(8.39)\end{array}$ & $\begin{array}{l}0.2751^{* * *} \\
(8.46)\end{array}$ \\
\hline $\begin{array}{l}\text { Log of total current } \\
\text { comp(salary+bonus) }\end{array}$ & $-0.2147 * * *$ & $-0.2179 * * *$ & $-0.1896^{* * *}$ & $-0.1921 * * *$ & $-0.3163 * * *$ & $-0.3197 * * *$ & $-0.2467 * * *$ & $-0.2486 * * *$ \\
\hline & $(-3.38)$ & $(-3.43)$ & $(-3.44)$ & $(-3.49)$ & $(-5.90)$ & $(-6.02)$ & $(-6.16)$ & $(-6.26)$ \\
\hline Market-to-book ratio & $\begin{array}{l}-0.0052 \\
(-0.83)\end{array}$ & $\begin{array}{l}-0.0052 \\
(-0.83)\end{array}$ & $\begin{array}{l}-0.002 \\
(-0.36)\end{array}$ & $\begin{array}{l}-0.002 \\
(-0.36)\end{array}$ & $\begin{array}{l}-0.0007 \\
(-0.11)\end{array}$ & $\begin{array}{l}-0.0006 \\
(-0.10)\end{array}$ & $\begin{array}{l}-0.0027 \\
(-0.59)\end{array}$ & $\begin{array}{l}-0.0026 \\
(-0.59)\end{array}$ \\
\hline Sales growth & $\begin{array}{l}-0.0529 \\
(-0.29)\end{array}$ & $\begin{array}{l}-0.0518 \\
(-0.28)\end{array}$ & $\begin{array}{l}0.1042 \\
(0.66)\end{array}$ & $\begin{array}{l}0.105 \\
(0.66)\end{array}$ & $\begin{array}{l}0.2075 \\
(1.24)\end{array}$ & $\begin{array}{l}0.2088 \\
(1.25)\end{array}$ & $\begin{array}{l}0.1082 \\
(0.86)\end{array}$ & $\begin{array}{l}0.1093 \\
(0.88)\end{array}$ \\
\hline $\mathrm{N}$ & 887 & 887 & 887 & 887 & 1,097 & 1,097 & 1,097 & 1,097 \\
\hline Adjusted R-squared & 0.35 & 0.35 & 0.43 & 0.43 & 0.28 & 0.29 & 0.38 & 0.38 \\
\hline
\end{tabular}




\begin{tabular}{|c|c|c|c|c|}
\hline $1^{\text {st }}$ stage results & $(1)$ & $(2)$ & $(3)$ & $(4)$ \\
\hline & \multicolumn{2}{|l|}{ Crisis Period } & \multicolumn{2}{|c|}{ Non-crisis Period } \\
\hline Controls & $\mathrm{k}$ & $\mathrm{k}^{*}$ & $\mathrm{k}$ & $\mathrm{k}^{*}$ \\
\hline \multirow[t]{2}{*}{ CEO vega/delta ratio } & $-0.0299 * * *$ & $-0.0301 * * *$ & $-0.0395 * * *$ & $-0.0397 * * *$ \\
\hline & $(-15.91)$ & $(-15.99)$ & $(-20.96)$ & $(-21.00)$ \\
\hline \multirow[t]{2}{*}{ Log of total current comp(salary+bonus) } & 0.0074 & 0.0276 & -0.0559 & -0.0444 \\
\hline & $(0.06)$ & $(0.21)$ & $(-0.51)$ & $(-0.40)$ \\
\hline \multirow[t]{2}{*}{ Log of firm age } & $0.3954 * * *$ & $0.4009 * * *$ & $0.192 * *$ & $0.1985^{* *}$ \\
\hline & $(4.20)$ & $(4.26)$ & $(2.46)$ & $(2.53)$ \\
\hline \multirow[t]{2}{*}{ Log of total assets } & -0.0453 & -0.0403 & -0.0183 & -0.0103 \\
\hline & $(-0.81)$ & $(-0.72)$ & $(-0.41)$ & $(-0.23)$ \\
\hline \multirow[t]{2}{*}{ Market-to-book ratio } & -0.0096 & -0.0097 & 0.0077 & 0.008 \\
\hline & $(-0.87)$ & $(-0.88)$ & $(0.74)$ & $(0.76)$ \\
\hline \multirow[t]{2}{*}{ Sales growth } & 0.282 & 0.2808 & $-0.4804 *$ & -0.4618 \\
\hline & $(0.88)$ & $(0.88)$ & $(-1.65)$ & $(-1.58)$ \\
\hline \multirow[t]{2}{*}{ Annual return } & 0.0712 & 0.0721 & $-0.2015 * *$ & $-0.2015 * *$ \\
\hline & $(0.39)$ & $(0.40)$ & $(-2.53)$ & $(-2.53)$ \\
\hline \multirow[t]{2}{*}{ Debt/equity ratio } & $-0.114 * * *$ & $-0.1137 * * *$ & $-0.7429 * * *$ & $-0.7427 * * *$ \\
\hline & $(-6.42)$ & $(-6.40)$ & $(-9.77)$ & $(-9.74)$ \\
\hline \multirow[t]{2}{*}{ Cash surplus } & $4.5033 * * *$ & $4.591 * * *$ & $4.8906 * * *$ & $4.8933 * * *$ \\
\hline & $(4.68)$ & $(4.77)$ & $(6.03)$ & $(6.02)$ \\
\hline \multirow{2}{*}{ Tax status } & $-0.3105 * *$ & $-0.3116 * *$ & $-0.2969 * * *$ & $-0.2972 * * *$ \\
\hline & $(-2.56)$ & $(-2.57)$ & $(-3.16)$ & $(-3.15)$ \\
\hline \multirow[t]{2}{*}{ New CEO } & 0.0396 & 0.0205 & -0.2134 & $-0.2486 *$ \\
\hline & $(0.25)$ & $(0.13)$ & $(-1.46)$ & $(-1.69)$ \\
\hline \multirow[t]{2}{*}{ Liquidity constraint } & 0.2855 & 0.2912 & 0.1732 & 0.148 \\
\hline & $(0.98)$ & $(1.00)$ & $(0.60)$ & $(0.51)$ \\
\hline \multirow[t]{2}{*}{ State wage tax rate } & $3.4687^{*}$ & $3.3739 *$ & $2.598 *$ & $2.4907 *$ \\
\hline & $(1.78)$ & $(1.73)$ & $(1.77)$ & $(1.70)$ \\
\hline $\mathrm{N}$ & 887 & 887 & 1,097 & 1,097 \\
\hline Adjusted R-squared & 0.38 & 0.39 & 0.47 & 0.47 \\
\hline
\end{tabular}




\section{Figure 1}

The graph in the top left presents the average of the difference between raw CEO to firm debt/equity ratio ( $\mathrm{k}$ ) and adjusted CEO to firm debt/equity ratio ( $\mathrm{k}^{*}$ ) for different Moody's credit ratings. The graph in the bottom left presents the average of the difference between $\mathrm{k}$ and $\mathrm{k}^{*}$ during and outside of the credit crisis. The table on the right covers the full regression sample from 2006-2010 but the graphs only include observations where $\mathrm{k}^{*}<10$. For firms whose bonds' ratings are available, we use the reasonable rating that is selected according to our decision rules and for a firm without bonds' ratings, we use the average rating of its comparable companies ("SIC two" and "Firm size").

\begin{tabular}{|c|c|c|c|c|c|}
\hline \multirow{2}{*}{\multicolumn{2}{|c|}{ Mean $\left(k-k^{*}\right)$ : Full Sample }} & \multicolumn{4}{|c|}{ Mean $\left(\mathrm{k}-\mathrm{k}^{*}\right)$} \\
\hline & & \multirow{2}{*}{$\begin{array}{l}\text { Moody's } \\
\text { Aaa }\end{array}$} & Full Sample & Credit Crisis & $\begin{array}{c}\text { Non-Credit } \\
\text { Crisis }\end{array}$ \\
\hline 0.3 & & & 0.0002 & 0.0000 & 0.0003 \\
\hline & & Aa1 & 0.0083 & 0.0020 & 0.0146 \\
\hline 0.2 & & $\mathrm{Aa} 2$ & 0.0002 & 0.0002 & 0.0001 \\
\hline 0.1 & & $\mathrm{Aa} 3$ & 0.0060 & 0.0106 & 0.0026 \\
\hline 0 & $n_{1} n_{1}, n_{1} n_{1} n_{1} n_{1} n_{1}$ & A1 & 0.0184 & 0.0116 & 0.0239 \\
\hline \multirow{2}{*}{\multicolumn{2}{|c|}{ 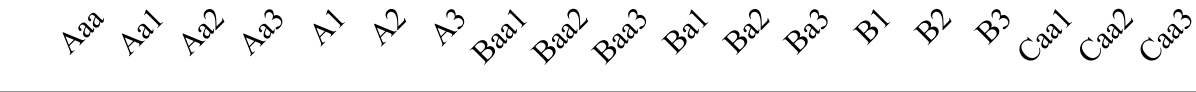 }} & A2 & 0.0191 & 0.0109 & 0.0257 \\
\hline & & A3 & 0.0117 & 0.0140 & 0.0100 \\
\hline \multirow{2}{*}{\multicolumn{2}{|c|}{ Mean(k-k*): Crisis versus Non-crisis }} & Baa1 & 0.0315 & 0.0307 & 0.0320 \\
\hline & & $\mathrm{Baa} 2$ & 0.0230 & 0.0196 & 0.0261 \\
\hline \multirow{10}{*}{$\begin{array}{r}1 \\
0.9 \\
0.8 \\
0.7 \\
0.6 \\
0.5 \\
0.4 \\
0.3 \\
0.2 \\
0.1\end{array}$} & & Baa3 & 0.0280 & 0.0273 & 0.0287 \\
\hline & & Ba1 & 0.0529 & 0.0505 & 0.0554 \\
\hline & & $\mathrm{Ba} 2$ & 0.0441 & 0.0446 & 0.0435 \\
\hline & & $\mathrm{Ba} 3$ & 0.0605 & 0.0957 & 0.0404 \\
\hline & & B1 & 0.0861 & 0.0707 & 0.1014 \\
\hline & & $\mathrm{B} 2$ & 0.2089 & 0.2994 & 0.1637 \\
\hline & & B3 & 0.0265 & 0.0396 & 0.0181 \\
\hline & & Caa1 & 0.0000 & 0.0000 & 0.0319 \\
\hline & 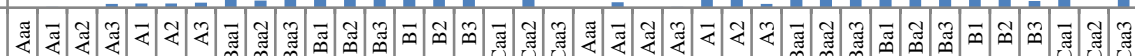 & $\mathrm{Caa} 2$ & 0.3637 & 0.8615 & 0.0000 \\
\hline & 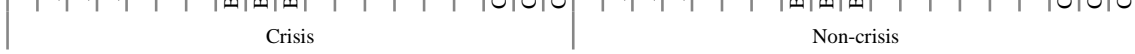 & $\mathrm{Caa} 3$ & 0.1531 & 0.0000 & 0.1531 \\
\hline
\end{tabular}




\section{[Appendix A] Details of CEO credit adjusted inside debt measure $\left(\mathrm{k}^{*}\right)$ calculation}

In this appendix we provide the details of how $\mathrm{k}^{*}$ is calculated by detailing each component of $\mathrm{k}^{*}$ calculation.

\section{CEO Decision Horizon [CEO DH]}

We assume that all debt owed to the CEO is paid at CEO retirement. Absent detailed data on the inside debt itself (contract terms and such), we believe that this is a reasonable assumption that we are required to make. We also assume that inside debt owed to the CEO is unsecured (Cassell et al, 2012). We use publicly-traded debt rating to proxy for the credit quality of the inside debt owed to the CEO. In our empirical tests, we obtain the firm's credit rating on its senior and unsecured debt (with the "appropriate maturity") and, therefore, the estimated default probability and recovery rate on that debt. The proxy for Maturity used is the CEO's expected decision horizon with the firm (Antia, Pantzalis, and Park, 2010).

$$
D H_{i, t}=\left[\text { Tenure }_{\text {ind }, t}-\text { Tenure }_{i, t}\right]+\left[\text { Age }_{\text {ind }, t}-\text { Age }_{i, t}\right]
$$

The estimation of expected CEO DH requires information on CEO tenure. CEO tenure in a given year is determined as the length of time between the date when the person becomes the CEO ("becameceo" in EXECUCOMP) and the current fiscal year end. Following Chen and Zheng (2014), we further make the following corrections: (1) For those observations with missing values from the above calculation, if the CEO is hired from outside the firm and the date when the person joined the company ("joined_co" in EXECUCOMP) is available, CEO tenure in a given year is calculated as the length of time between "joined_co" and the current fiscal year end. Similar to Allgood and Farrell (2000), Farrell and Whidbee (2002), and Huson et al., 2004, a $\mathrm{CEO}$ is considered an outside hire if she joins the firm for less than two years at the time of succession and she is not a founder; (2) For those CEOs who held the position multiple times, EXECUCOMP only has the data for "becameceo" for either the first time or the most recent time the person became the CEO. Therefore, we manually check these cases and use the information that the previous CEO left the company to determine the data for "becameceo" for the CEO with multiple appointments.

Following these amendments, for those CEOs whose tenure still can't be determined, it is generally the case that the person became CEO too early to be covered by Execucomp (Execucomp coverage is from 1992-present). Therefore, we search these persons on the internet to determine the date they became CEO: if no specific date is available on the internet, but we know the year $\mathrm{Y}$ and the month $\mathrm{M}$ he became CEO, we assume that he became CEO on the first day of month $\mathrm{M}$ in year $\mathrm{Y}$; if we only know the year he became CEO, we use the fiscal year beginning date in year Y; for the rest of CEOs, we use the date he joined company or the date he founded the company as the date he became CEO. After these adjustments, all CEO tenures are positive. In this process, we also find that there are cases when the CEO identification in Execucomp (CEOANN) is incorrect, we correct these cases by checking DEF 14A and annual title in Execucomp.

Industry median Tenure ind,t and Age ind,t values are computed at the two-digit SIC code level and all variables are measured at the end of year $t$.

\section{Default Probability and Recovery Rate [DP and RR]}

We provide detailed description of how we estimate the cumulative default probability and expected recovery rate. We use Mergent Fixed Income Securities Database (FISD) to gather data 
on bond ratings and maturities. Per assumptions made above, we need to identify senior and unsecured US corporate debt. More specifically,

a) The variable Security_level in Mergent FISD indicates whether the security is a secured, senior or subordinated issue of the issuer. We set Security_level="SEN" to identify senior issues.

b) We focus on public debt issuance of corporate bonds, the Mergent FISD bond sample includes bond types CDEB, CMTN, CMTZ, CCOV, USBN, CS, CCPI, CZ and UCID.

c) We also exclude (1) bonds that are foreign denominated, Yankee, Canadian entity issued, Rule 144a issues, issuances only offered privately to selected individuals and institutions; (2) bonds with credit enhancement, secured by one or more leases, collateralized by a portfolio of loans or assets; (3) bonds with equity-like features (perpetual, preferred security); (4) structured products; (5) bonds already in default.

Moody's, S\&P, and Fitch use similar but divergent systems of rating bond issues. The following table displays the reference codes used to integrate the rating systems. Mergent FISD (2012) employs comparable reference codes 1 through 25 in its database. We mainly use Moody's rating because Moody's provides expected recovery rates of different ratings publicly, while we can't obtain cumulative default rates and expected recovery rates from S\&P and Fitch. Therefore, unless otherwise stated, our discussions are all based on Moody's ratings. We collect Moody's reporting on cumulative default rate manually. Cumulative global default rates and recovery rates are available in Moody's annual study report "Corporate Default and Recovery Rates, 19202006".

\begin{tabular}{|c|c|c|c|}
\hline $\begin{array}{c}\text { Reference } \\
\text { codes }\end{array}$ & Fitch Rating & S\&P's Rating & Moody's Rating \\
\hline 1 & AAA & AAA & Aaa \\
\hline 2 & $\mathrm{AA}+$ & $\mathrm{AA}+$ & Aa1 \\
\hline \multirow{2}{*}{3} & \multirow{2}{*}{ AA } & \multirow{2}{*}{ AA } & $\mathrm{Aa}$ \\
\hline & & & $\mathrm{Aa} 2$ \\
\hline 4 & AA- & AA- & $\mathrm{Aa} 3$ \\
\hline 5 & $\mathrm{~A}+$ & $\mathrm{A}+$ & A1 \\
\hline \multirow{2}{*}{6} & \multirow{2}{*}{ A } & \multirow{2}{*}{ A } & $\mathrm{A}$ \\
\hline & & & $\mathrm{A} 2$ \\
\hline 7 & A- & A- & $\mathrm{A} 3$ \\
\hline 8 & $\mathrm{BBB}+$ & $\mathrm{BBB}+$ & Baa1 \\
\hline \multirow{2}{*}{9} & \multirow{2}{*}{ BBB } & \multirow{2}{*}{ BBB } & Baa \\
\hline & & & Baa2 \\
\hline 10 & BBB- & BBB- & Baa3 \\
\hline 11 & $\mathrm{BB}+$ & $\mathrm{BB}+$ & Ba1 \\
\hline \multirow{2}{*}{12} & \multirow{2}{*}{ BB } & \multirow{2}{*}{ BB } & $\mathrm{Ba}$ \\
\hline & & & $\mathrm{Ba} 2$ \\
\hline 13 & BB- & BB- & $\mathrm{Ba} 3$ \\
\hline 14 & $\mathrm{~B}+$ & $\mathrm{B}+$ & $\mathrm{B} 1$ \\
\hline \multirow{2}{*}{15} & \multirow{2}{*}{ B } & \multirow{2}{*}{ B } & $\mathrm{B}$ \\
\hline & & & $\mathrm{B} 2$ \\
\hline 16 & B- & B- & B3 \\
\hline 17 & $\mathrm{CCC}+$ & $\mathrm{CCC}+$ & Caa1 \\
\hline
\end{tabular}




\begin{tabular}{cccc}
\hline \multirow{2}{*}{18} & CCC & CCC & Caa \\
\cline { 3 - 4 } & & CCC- & Caa2 \\
\hline 19 & CCC- & CC & Ca \\
\hline 20 & CC & CC & C \\
\hline 21 & C & C & \\
\hline 22 & & & \\
\hline 23 & DDD & & \\
\hline 24 & DD & & \\
\hline 25 & D & D & \\
\hline
\end{tabular}

a) Cumulative default probability.

Moody's updates statistics on the cumulative global default rates both by letter ratings and by alphanumeric ratings since 1920 in their annual default study, while S\&P provides cumulative global default rates only for letter rating. As mentioned above, we exclude bonds that have defaulted (reference code $>21$ ), and are only interested in reference codes 1 through 21 . Therefore, consistent with the letter rating categories, we divide ratings into 8 groups, as shown in the table below. Moody's provides cumulative default rates for years 1 through 20 . For those bonds whose time to maturity is longer than 20 years, we use the default rate for 20 years.

\begin{tabular}{|l|l|}
\hline Rating Group & Reference codes \\
\hline 1 & 1 \\
\hline 2 & $2,3,4$ \\
\hline 3 & $5,6,7$ \\
\hline 4 & $8,9,10$ \\
\hline 5 & $11,12,13$ \\
\hline 6 & $14,15,16$ \\
\hline 7 & $17,18,19$ \\
\hline 8 & 20,21 \\
\hline
\end{tabular}

b) Recovery rates.

Moody's provides information on the recovery rates based on issuer rating at various points in time prior to default, but only for up to 5 years. For years $>5$, we use the recovery rates for year 5 . The following table shows the cumulative default rates and expected recovery rates reported by Moody's in 2011 (Source: “Average Cumulative Credit Loss Rates by Letter Rating, 1982-2011" in Moody's "Corporate Default and Recovery Rates, 1920-2011"). For instance, according to this table the recovery rate of bonds rated AA at any point in time up to five years prior to default is $0.22 \%$.

\begin{tabular}{|r|r|r|r|r|r|r|}
\hline \multicolumn{1}{|l|}{ Fiscal Year } & \multicolumn{1}{l|}{ Rating } & \multicolumn{1}{l|}{ Year 1 } & \multicolumn{1}{l|}{ Year 2 } & \multicolumn{1}{l|}{ Year 3 } & \multicolumn{1}{l|}{ Year 4 } & \multicolumn{1}{l|}{ Year 5 } \\
\hline 2011 & AAA & $0.00 \%$ & $0.01 \%$ & $0.01 \%$ & $0.02 \%$ & $0.03 \%$ \\
\hline 2011 & AA & $0.01 \%$ & $0.04 \%$ & $0.09 \%$ & $0.14 \%$ & $0.22 \%$ \\
\hline 2011 & A & $0.05 \%$ & $0.13 \%$ & $0.24 \%$ & $0.37 \%$ & $0.52 \%$ \\
\hline 2011 & Baa & $0.12 \%$ & $0.31 \%$ & $0.56 \%$ & $0.83 \%$ & $1.12 \%$ \\
\hline 2011 & Ba & $0.62 \%$ & $1.80 \%$ & $3.30 \%$ & $4.95 \%$ & $6.34 \%$ \\
\hline
\end{tabular}




\begin{tabular}{|r|r|r|r|r|r|r|}
\hline 2011 & B & $2.62 \%$ & $6.30 \%$ & $9.93 \%$ & $13.05 \%$ & $15.77 \%$ \\
\hline 2011 & Caa-C & $10.89 \%$ & $18.39 \%$ & $24.51 \%$ & $29.36 \%$ & $33.61 \%$ \\
\hline * Based on average default rates and senior unsecured bond recoveries measured on issuer-weighted basis. \\
\hline
\end{tabular}

\section{[Maturity]}

By definition, time to-maturity (TTM) is the length of time until the expiration of the bond contract. We use two maturities in our empirical tests, initial maturity (TTM_initial) and remaining maturity (TTM_remain). Initial maturity is the time from bonds' offering date to maturity, while remaining maturity is the difference between the rating date and maturity. For brevity, we only show results for TTM_type=initial as results for TTM_type=remain are quite similar.

$$
T T M=\left\{\begin{array}{c}
T T M \_ \text {initial }=(\text { Maturity }- \text { offering_date }) / 365 \\
T T M \_r e m a i n=(\text { Maturity }- \text { rating_date }) / 365
\end{array}\right.
$$

The rating we assign to firm $\mathrm{A}$ in year $\mathrm{t}$ is the most recent rating of the most "qualified" bonds issued by firm A. The most "qualified" bonds refer to the bonds that can best capture the maturity of CEO's inside debt.

As mentioned earlier, the CEO's expected decision horizon (DH) adjusted for industry median age and industry median tenure (Antia, Pantzalis, and Park, 2010) can be positive or negative. When the $\mathrm{CEO} \mathrm{DH}$ is not positive $(\mathrm{DH}<0)$ or near zero (rounded $\mathrm{DH}=0$ ) (i.e., the CEO is older and/or has been in office for longer than the benchmark), we assume that they retire immediately, and no adjustments are needed. But for positive CEO DH, we adjust the inside debt holdings (VED) for expected cumulative default probability (DP) and expected recovery rate (RR). Formulaically,

$$
E L= \begin{cases}V E D & D H \leq 0 \\ V E D * D P *(1-R R) & D H>0\end{cases}
$$

For CEOs with positive $\mathrm{DH}$, we determine the maturity of inside debt through comparing the CEO's expected decision horizon(DH), the bond's time-to-maturity (TTM) and the years to default (YTD) defined in Moody's calculation of recovery rate for specific rating group (e.g., rating=AA group). As described above, YTD can be $\{1,2,3,4,5 \ldots \ldots 19,20\}$. Specifically, for CEOs with rounded $(\mathrm{DH})>0$, the final proxy of the maturity of inside debt (Maturity) is arrived at using the following rules applied in order:

a) We choose Moody's latest credit rating of bonds (bonds whose rating date is closest to firms' fiscal year end date.)

b) Conditional on a), we choose the issue whose abs (DH-TTM) is the smallest.

c) Conditional on b), if there are issues satisfying abs (DH-TTM) $<=1$, which means that there is a bond whose TTM is almost the same as CEO's expected decision horizon, we use the default probability and recovery rate of YTD whose abs(YTD-TTM) is the smallest.

d) Conditional on b), if abs(DH-TTM) $>1$ for all issues, which means that there isn't any bond of the firm whose TTM is very close to CEO's expected decision horizon, we calculate $\operatorname{abs}(\mathrm{DH}-\mathrm{YTD})$ for all $\mathrm{YTD}=\{1,2,3,4,5\}$, and use the default probability and recovery rate of YTD whose abs(DH-YTD) is the smallest. 


\section{[Appendix B] Variable Derivation}

In this appendix we provide the details of how each variable used in the regression models is calculated or sourced. In the first section we outline each of the ten components of the CEO's inside debt measure and in the second section we provide definitions for our control variables.

\section{Calculation of CEOs' inside debt measure}

[1]Dividend yield. Execucomp uses dividend yield estimates over a rolling 3 year window in B$\mathrm{S}$ calculations. As such, the estimated dividend yield is the company's average dividend yield over the past 3 years leading up to the beginning of the fiscal periods. Execucomp winsorizes the dividend yield at the 5th and 95th percentiles, which is a procedure we follow as well.

[2]Volatility. Execucomp uses volatility estimates over a rolling 5 year window in B-S calculations. As such, the estimated volatility is the annualized standard deviation of stock returns estimated over the 60 months leading up to the beginning of the fiscal periods. Execucomp winsorizes volatility values at the 5th and 95th percentiles, which is a procedure we also follow. For firms with less than 12 months of data for that year, the average volatility of S\&P1500 firms is used instead.

[3]Risk-free rate. We download the annual Treasury rates for 2006-2012 from the Federal Reserve website (file fed_website_10yrTnote in Excel). We use the risk-free rate that corresponds to actual maturity. While Execucomp assumes a 70\% haircut on time to maturity and uses a 7 year maturity for newly granted options, and therefore uses the 7 year risk-free rate for grant date valuation, we use the actual rounded maturity (expiration date minus fiscal year end date). Note that since the FED website gives only 1, 2, 3, 5, 7 and 10-year rates, we interpolate the numbers for years $4,6,8$, and 9 .

\section{[4]CEO stock option valuation.}

Executives' equity holdings include both stock ownership and the stock options. We apply the Black-Scholes (1973) option model to value each individual tranche of options held by the executives (e.g., exercisable and un-exercisable) and sum the tranche values to a grand total. We calculate B-S value of options granted using Execucomp methodology following Coles, Daniel and Naveen (2013), considering that "OA" methodology used in Cassell et al. (2012) is not consistent with the FAS 123R issued by the FASB in 2004 and SEC amendments in 2006. To value stock options, we use the Black-Scholes (1973) model modified by Merton (1973) to account for dividend payouts.

where:

$$
V_{\text {option }}=S e^{-d T} N(Z)-X e^{-r T} N(Z-\sigma \sqrt{T})
$$

$$
Z=\frac{\ln \left(\frac{S}{X}\right)+T\left(r-d+\frac{\sigma^{2}}{2}\right)}{\sigma \sqrt{T}}
$$

$\mathrm{N}$ : the cumulative probability function for the normal distribution;

$\mathrm{S}$ : the price of the underlying stock; 
$\mathrm{X}$ : the exercise price of the option;

$\sigma:$ the expected stock-return volatility over the life of the option

r: the natural logarithm of risk-free interest rate;

$\mathrm{T}$ : the time-to-maturity of the option in years;

d: the natural logarithm of expected dividend yield over the life of the option.

Cassell et al. (2012) estimate newly granted options using the grant-specific information disclosed in annual proxy statement. To value previously granted options, they follow Core and Guay's (2002) "one year approximation" (OA) process.

We compute incentives as of fiscal year-end following Coles, Daniel and Naveen (2013), using only the unexercised unexercisable options and unexercised exercisable options. This is because: 1) FAS $123 \mathrm{R}$ issued by the FASB in 2004 and SEC amendments in 2006, and 2) our sample focuses on observations after 2007 and those in 2006 under the new reporting format.

Execucomp provides a separate record for each outstanding option tranche (denoted by a different value of OUTAWDNUM), indicating the number of vested, unvested, and unearned options (OPTS_UNEX_EXER, OPTS_UNEX_UNEXER, OPTS_UNEX_UNEARN) of each tranche, and their corresponding exercise price (EXPRIC) and expiration date (EXDATE).

To calculate the option values of executives' compensation, we require the following:

\begin{tabular}{|l|l|}
\hline Inputs & Variables in Compustat \\
\hline Stock price & prcc_f \\
\hline Expected stock-return volatility & estimated_sigma \\
\hline Expected dividend yield & estimated_yield \\
\hline Exercise price & Expric \\
\hline Time-to-maturity & maturity=(exdate-datadate)/365 \\
\hline Risk-free rate & RF \\
\hline \# of unexercised exercisable options & OPTS_UNEX_EXER \\
\hline \# of unexercised unexercisable options & OPTS_UNEX_UNEXER \\
\hline
\end{tabular}

For a small percentage of observations, maturity is indicated to be smaller than -1 . This is obviously unusual so we check the "Outstanding Equity Awards" in prior years' DEF 14A and compare it with other executives' stock option grants and find that this occurs most likely due to recoding error. For these cases, we add 10 years to the expiration date to arrive at a reasonable maturity.

When there are multiple grants for the same executive in the same year, data on the maturity of one option award is sometimes missing or negative even though other awards in that year have data on maturity. In these cases, we replace the maturity and exercise price that is missing or negative with the average maturity of the other awards granted to the same executive in the same year. For rounded maturity that is less than 1 or greater than 10 years, we use 1 year and 10 year annual treasury rates to proxy the risk-free rates respectively. 
Detailed information on option tranches is included in the "Outstanding Awards Table" in Compustat Execucomp. We find that there are cases when sums of the tranche numbers of options (unvested and vested) don't equal to the total option grants in "Execucomp Anncomp Table". We check these cases manually, and use the actual data in the "Outstanding Awards Table" of DEF 14A for those cases whose information on tranche information in Execucomp is incorrect (incomplete tranches or wrong number of individual tranche).

After obtaining the value of each option, we sum the tranche values to arrive at a grand total. Denoting the value of an unexercised unexercisable option and an unexercised exercisable option as Value_unex and Value_ex, we have:

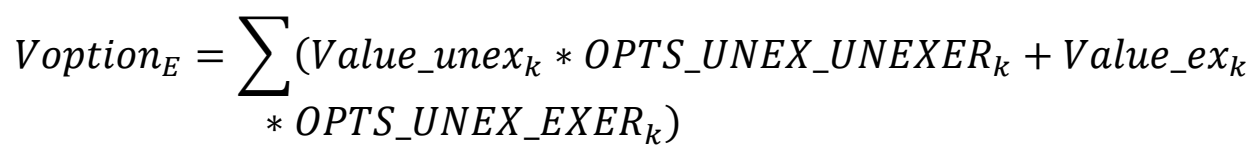

For more on stock option valuation, please see Coles, J., Daniel, N., Naveen, L., 2013; Coles, J., Naveen, N., Naveen, L., 2006; Daniel, N., Li, Y., and Naveen, L. 2013;

[5]CEO stock ownership. We calculate the value of stocks held by the executives by multiplying the number of shares held (including restricted shares) by the stock price at the firm's fiscal year-end. SHROWN_TOT (SHROWN_EXCL_OPTS) is the shares owned by the executive, including (excluding) options that are exercisable or will become exercisable within 60 days. Following previous research (Coles, Daniel and Naveen, 2013), we deduct options that become exercisable within 60 days after the proxy statement to avoid double counting the options in the outstanding equity table. Therefore, we have:

$$
\text { Vstock }_{E}=\text { prcc_f } f * S H R O W N_{-} E X C L_{-} O P T S
$$

The data items required are:

\begin{tabular}{|l|l|}
\hline Inputs & Variables \\
\hline Stock price & prcc_f \\
\hline Number of shares held & SHROWN_EXCL_OPTS \\
\hline
\end{tabular}

[6]CEO Equity holdings.

$$
\text { Vequity }_{E}=\text { Voption }_{E}+\text { Vstock }_{E}
$$

[7]CEO inside debt holdings. The sum of the present value of accumulated pension benefits (PENSION_VALUE_TOT) and deferred compensation (DEFER_BALANCE_TOT) as reported in Execucomp.

$$
V E D=\text { PENSION_VALUE_TOT + DEFER_BALANCE_TOT }
$$

[8]Firm equity. The market value of equity is calculated as the price of the share at the end of the fiscal year prcc $\mathrm{f}$ (Price Close - Annual - Fiscal) times the number of outstanding shares CSHO (Common Shares Outstanding) at the end of the fiscal year.

$$
V E E=P R C C_{-} F * C S H O
$$


[9]Firm delta. Similar to CEO delta, we adopt the definition of delta in Core and Guay (2002). For firm delta, three required inputs to the Black-Scholes formula are stock price, expected stock-return volatility, expected dividend yield. These are the same items used in the calculation of CEO delta. Other inputs are listed in the following table:

\begin{tabular}{|l|l|}
\hline Inputs & Variables in Compustat \\
\hline Exercise price & OPTPRCEY \\
\hline Time-to-maturity & 4 \\
\hline Risk free rate & 4 year Treasury bill rates \\
\hline Options outstanding & OPTOSEY \\
\hline
\end{tabular}

$$
\text { Delta }_{F}=\Delta V F E=C S H O * P R C C_{-} F * 0.01+e^{-4 * d} * N(Z) * P R C C_{-} F * O P T O S E Y * 0.01
$$

[10]Firm debt. Total firm debt includes current debt DLC (Debt in Current Liabilities - Total) and long-term debt DLTT (Long-Term Debt - Total).

$$
V F D=D L C+D L T T
$$

\section{Control variables}

\begin{tabular}{|c|c|}
\hline Controls & Descriptions \\
\hline CEO vega/delta ratio & Vega_Delta $=\left(\text { Vega }_{\mathrm{E}} / \text { Delta }_{\mathrm{E}}\right)^{*}\left(\right.$ Vequity $\left._{\mathrm{E}} / \mathrm{Vdebt}_{\mathrm{E}}\right)$ \\
\hline Log of total current comp(salary+bonus) & LogCurr= $\ln$ (Total Curr) \\
\hline Log of firm age & logfirm age $=\ln ($ firm age $)$ \\
\hline Log of total assets & $\log \mathrm{AT}=\ln (\mathrm{AT})$ \\
\hline Market-to-book ratio & $\begin{array}{l}\mathrm{M} 2 \mathrm{~B}=\mathrm{CSHO} * \text { prcc f/CEQ, where CEQ is the total } \\
\text { Common/Ordinary Equity. }\end{array}$ \\
\hline Sales growth & Psale $=$ REVT(Revenue - Total) in year $\mathrm{t} / \mathrm{REVT}$ in year $\mathrm{t}-1$ \\
\hline Annual return & $\begin{array}{l}\text { ARET }=(\text { prcc_f at fiscal year t-prcc_f at fiscal year t-1)/prcc_f at } \\
\text { fiscal year } t-1\end{array}$ \\
\hline Debt/equity ratio & $\mathrm{D} 2 \mathrm{E}=(\mathrm{DLC}+\mathrm{DLTT}) /(\mathrm{CSHO} *$ prcc_f $)$ \\
\hline Cash surplus & $\begin{array}{l}\text { CS2AT }=(\text { net cash flow from operations (OANCF)-Depreciation } \\
\text { expenses (DPC)+Research and development } \\
\text { expenditures(XRD))/Total assets(AT); We set XRD to zero if XRD } \\
\text { is missing. }\end{array}$ \\
\hline Industry fixed effect & 1 or 0 \\
\hline Year fixed effect & 1 or 0 \\
\hline
\end{tabular}

Definitions and descriptions of controls are listed in the following table:

Since there is no direct variable indicating firms' age in CRSP and Compustat we estimate firm age by identify the first fiscal year that the firm appeared in Compustat and use the beginning date of that fiscal year to mark the "birth" of the firm. Firm age is the difference between firm birth and the current fiscal year end.

In the above table, we calculate CEO delta and vega following Coles, Daniel and Naveen (2013). In calculating option delta and vega, we use only unexercised unexercisable options and 
unexercised exercisable options. We do not use unearned awards (e.g., unvested awards for which future vesting is contingent or accelerated based on achieving stock price or accounting hurdles) because the data required to calculate incentives for these awards are not available in electronic format in Execucomp for any firm. Ignoring the unearned awards has the effect of underestimating true delta and vega. These unearned shares or options will be classified as either shares or options when they are earned, and, if these grants are still held by the executive as of the end of the year, they will be included in the delta and vega calculations at that time.

\section{Delta}

To compute overall equity delta, we add the delta of the portfolio of options and the delta of the portfolio of shares. Execucomp provides the number of restricted stocks outstanding at the end of each year (SHRS_UNVEST_NUM), but not data on unrestricted stock holding. Therefore we use the variable SHROWN_EXC̄L_OPTIONS, which is the sum of both restricted and unrestricted shares. That is,

$$
\begin{gathered}
\text { Delta }_{E}=\Delta V E E=\text { Stock Delta }+ \text { Option Delta } \\
\text { Delta }_{E}=\Delta V E E=S H R O W N_{-} E X C L_{-} O P T I O N S * P R C C_{-} F * 0.01+\sum\left(N_{i} * \Delta N_{i}\right)
\end{gathered}
$$

where:

$N_{i}$ is the number of options in tranche $\mathrm{i}$ and $\Delta N_{i}$ is the option delta for tranche $\mathrm{i}$, defined as the following:

\begin{tabular}{|l|l|l|}
\hline \multicolumn{1}{|c|}{ Variables } & Variables in Compustat & \multicolumn{1}{c|}{ Description } \\
\hline \multirow{2}{*}{$\mathrm{N}_{\mathrm{i}}$} & OPTS_UNEX_UNEXER & $\begin{array}{l}\text { Amount of securities underlying Unexercised } \\
\text { unexercisable options }\end{array}$ \\
\cline { 2 - 3 } & OPTS_UNEX_EXER & $\begin{array}{l}\text { Amount of securities underlying Unexercised } \\
\text { exercisable options }\end{array}$ \\
\hline
\end{tabular}

And $\Delta N_{i}$ is the option delta for tranche i. According to Core and Guay (2002), the sensitivity with respect to one percent change in stock price is

$$
\frac{\partial(\text { option value })}{\partial(\text { price })} * \frac{\text { price }}{100}=e^{-d T} * N(Z) * \text { price } / 100
$$

Namely, $\Delta N_{i}=e^{-d T} * N(Z) *$ price $/ 100$

\section{Vega}

For vega of the equity portfolio, we use only the vega of the option portfolio calculated above. We assume, as in Guay (1999), that vega of the share portfolio is zero. That is

$$
\operatorname{Veg} a_{E}=\sum\left(N_{i} * \theta_{i}\right)
$$

And $\theta_{i}$ is the option vega for tranche i. According to Core and Guay (2002), the sensitivity with respect to one percent change in stock return volatility is

$$
\frac{\partial(\text { option value })}{\partial(\text { stock volatility })} * \frac{1}{100}=e^{-d T} * N(Z) * \text { price } * T^{1 / 2} * 0.01
$$

Namely, $\theta_{i}=e^{-d T} * N(Z) *$ price $* T^{1 / 2} * 0.01$ 


\section{[Appendix C] Ridge Regression}

The standard OLS estimator of the regression coefficients is:

$$
\hat{\gamma}=\left(X^{\prime} X\right)^{-1} X^{\prime} Y
$$

Where $X$ is the independent variables, $Y$ is the dependent variable, and $\hat{\gamma}$ is the estimated coefficients using OLS. The OLS fits a linear model with coefficients to minimize the residual sum of squares (SSR) between the observed $Y$ and the predicted $\hat{Y}$ by the linear approximation. That is, $\hat{\gamma}$ solves the following optimization problem:

$$
\operatorname{Min} \operatorname{SSR}=\|X \gamma-Y\|^{2}
$$

It is commonly known that $\hat{\gamma}$ is the best linear unbiased estimate (BLUE) for $\gamma$. However, the coefficient estimates for OLS rely on the independence of the explanatory variables. When multicollinearity occurs, $\mathrm{X}$ becomes close to singular and the OLS estimates become highly sensitive to random errors, resulting in a large variance.

$$
\operatorname{Var}(\gamma)=\sigma^{2}\left(X^{\prime} X\right)^{-1}
$$

First developed by Hoerl and Kennard (1970a, b), and tested and extended by others (e.g., Lowerre, 1974; Farebrother, 1975; Vinod, 1978; Kutner et al., 2004), ridge regression, as a multivariate technique, modifies the OLS estimation in order to minimize the variance in $\gamma$ by incorporating a small amount of bias into the estimating equation.

Through imposing a penalty on the size of coefficients, the ridge regression aims to minimize the sum of SSR and the variance of $\gamma$. As an optimization problem, the ridge estimates minimize the following cost function, a penalized residual sum of squares:

$$
\operatorname{Min} \operatorname{SSR}(\text { ridge })=\|X \gamma-Y\|^{2}+\lambda\|\gamma\|^{2}
$$

The ridge estimating equation is:

$$
\hat{\gamma}^{*}=\left(X^{\prime} X+\lambda I\right)^{-1} X^{\prime} Y
$$

Where the positive constant $\lambda(0<\lambda<1)$ is the added bias, called the ridge parameter, and $I$ is the identity matrix.

In other words, the ridge regression reduces a large portion of variance of $\gamma$ without increasing the penalized residual sum of squares SSR(ridge) to an unreasonable value through introducing an added constant $\lambda$. The ridge regression solution is identical to the OLS solution except for the term $\lambda I$ and is linear in the response variable $\mathrm{y}$. For a given bias $\lambda$, the ridge solution contains the minimum $\operatorname{SSR}_{\gamma}$ and decreases the variance in $\gamma$. Because the mean square error is a function of both bias and variance in $\gamma$, a small bias is acceptable if the ridge estimation reduces a larger portion of the variance in $\gamma$. Kutner et al. (2004) show that biased estimators with a small variance are preferable to unbiased estimators with a large variance, because the small variance estimators are less sensitive to the measurement errors. 
Hoerl and Kennard (1970) suggest the selection of the ridge parameter should: (1) stabilize the system such that it reflects an orthogonal (i.e., statistically independent) system. In practice, we think that a model is out of multicollinearity when VIF is smaller than 10; (2) lead to coefficients with reasonable values and ensure that coefficients with improper signs at $\mathrm{k}=0$ have switched to the proper sign; (3) ensure that the residual sum of squares is not inflated to an unreasonable value.

Following the procedure in Hoerl and Kennard (1970), Vinod (1978), and Marquette and Johnson (1980), we conduct the ridge regression analysis of $\log$ of total risk $t+1$ as below:

(1) Plot the ridge estimate $\hat{\gamma}^{*}$ for each variable against a range of values for the ridge parameter $\lambda$, termed "ridge traces". These graphs show how each variable reacts to the elimination of the non-orthogonality.

Denoting the "ridge traces" as $\hat{\gamma}^{*}(\lambda)$ and incrementing $\lambda$ from 0 to 0.02 by 0.002 , we get the ridge estimates of $\hat{\gamma}^{*}$ for different $\lambda$ 's. In Table $\mathrm{C} 1$ and Figure $\mathrm{C} 1$, we can see that the minimal $\mathrm{k}$ to reduce multicollinearity problem is 0.006 , where VIF value is below 10 , the rule of thumb value, suggesting no multicollinearity.

Table C1. VIF traces

\begin{tabular}{lll}
\hline $\boldsymbol{\lambda}$ & $\begin{array}{l}\text { VIF of Log of CEO to firm } \\
\text { debt/Equity ratio }\end{array}$ & $\begin{array}{l}\text { VIF of Log of Adjusted CEO to } \\
\text { firm debt/Equity ratio }\end{array}$ \\
\hline 0 & 801.1770 & 804.4366 \\
0.002 & 45.6213 & 45.8031 \\
0.004 & 14.9834 & 15.0394 \\
0.006 & 7.5221 & 7.5473 \\
0.008 & 4.6129 & 4.6261 \\
0.01 & 3.1841 & 3.1913 \\
0.012 & 2.3775 & 2.3815 \\
0.014 & 1.8777 & 1.8796 \\
0.016 & 1.5463 & 1.5468 \\
0.018 & 1.3151 & 1.3147 \\
0.02 & 1.1471 & 1.1460
\end{tabular}




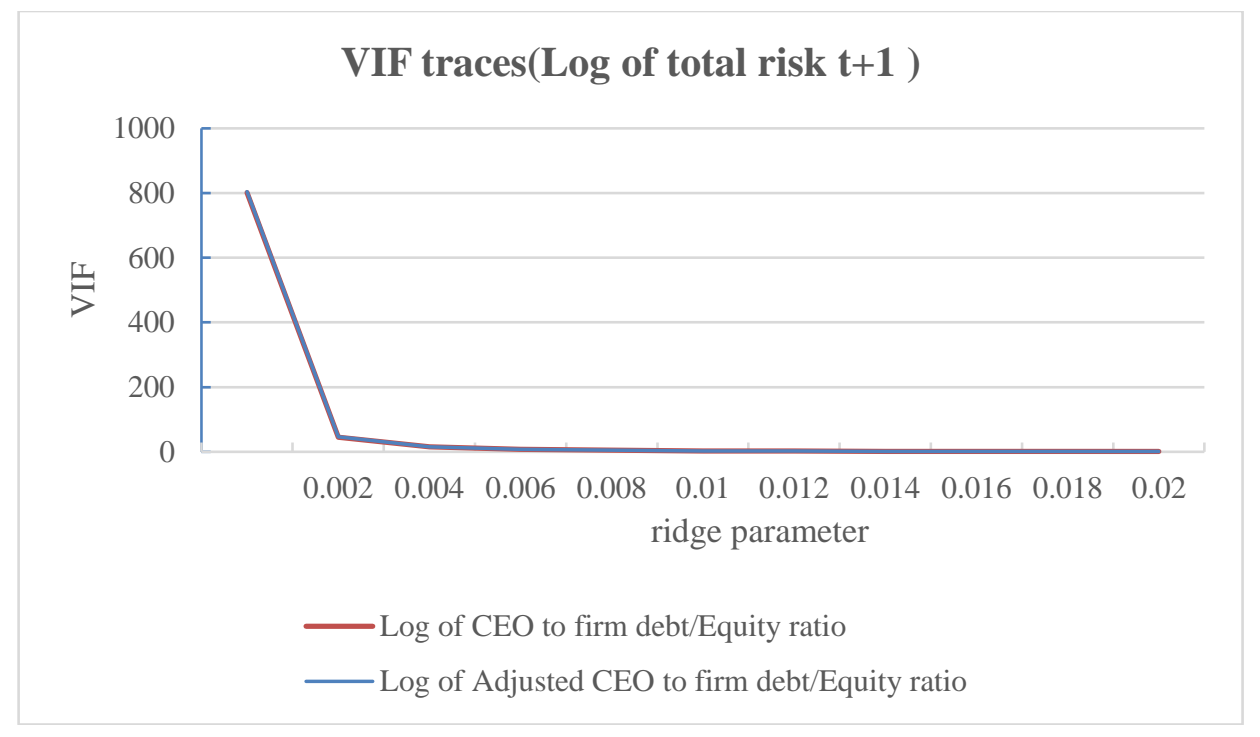

Figure C1: VIF versus Ridge Parameters

(2) Locate a value of $\lambda$ such that the $\gamma^{*}$ coefficient is economically reasonable and will yield an equation whose residual sum of squares is not inflated to an unreasonable value.

Table C2 and Figure C2 suggest that to ensure that the coefficients with reasonable sign, the ridge parameter should be no less than 0.008 .

Table C2. Standardized coefficients

\begin{tabular}{lll}
\hline $\boldsymbol{\lambda}$ & $\begin{array}{l}\text { Coefficients of Log of CEO to } \\
\text { firm debt/Equity ratio }\end{array}$ & $\begin{array}{l}\text { Coefficients of Log of Adjusted } \\
\text { CEO to firm debt/Equity ratio }\end{array}$ \\
\hline 0 & 0.4983 & -0.5904 \\
0.002 & 0.0845 & -0.1758 \\
0.004 & 0.0285 & -0.1198 \\
0.006 & 0.0063 & -0.0976 \\
0.008 & -0.0057 & -0.0857 \\
0.01 & -0.0132 & -0.0783 \\
0.012 & -0.0183 & -0.0733 \\
0.014 & -0.0221 & -0.0697 \\
0.016 & -0.0250 & -0.0669 \\
0.018 & -0.0272 & -0.0647 \\
0.02 & -0.0290 & -0.0630
\end{tabular}




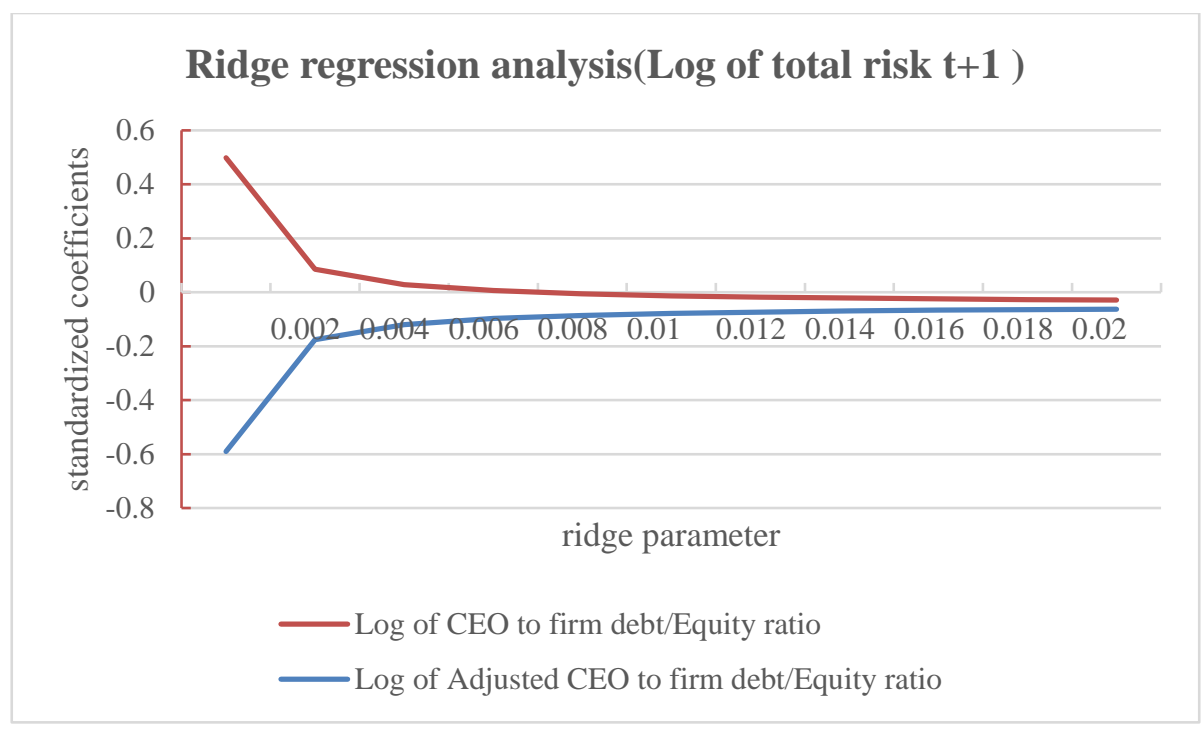

Figure C2: Standardized coefficients versus Ridge Parameter

(3) In ridge regression, the bias is an increasing function of the ridge parameter, and the ridge estimates are exactly the OLS estimates when the ridge parameter $\lambda=0$. In other words, the OLS yields the minimum SSR, and SSR increases as $\lambda$ increases. Therefore, to ensure the least SSR(regression sum of squares), we list the SSR's in Table C3 and show that the SSR's are only inflated slightly for all of our regressions. For example, for a ridge parameter 0.008 , the SSR increases by merely $0.1 \%$ on average.

Table C3. SSR inflation

\begin{tabular}{rllll}
\hline $\boldsymbol{\lambda}$ & $\begin{array}{c}\text { SSR } \\
\text { (Log of total } \\
\text { risk t+1) }\end{array}$ & $\begin{array}{c}\text { SSR } \\
\text { (Log of total } \\
\text { risk t+3) }\end{array}$ & $\begin{array}{c}\text { SSR } \\
\text { (Log of } \\
\text { idiosyncratic } \\
\text { risk t+1) }\end{array}$ & $\begin{array}{c}\text { SSR } \\
\text { (Log of } \\
\text { idiosyncratic } \\
\text { risk t+3) }\end{array}$ \\
\hline 0.000 & 752.238 & 1005.165 & 942.722 & 1304.270 \\
0.002 & 752.705 & 1005.277 & 943.679 & 1304.351 \\
0.004 & 752.877 & 1005.355 & 944.020 & 1304.433 \\
0.006 & 752.981 & 1005.449 & 944.227 & 1304.543 \\
0.008 & 753.067 & 1005.567 & 944.401 & 1304.687 \\
0.010 & 753.151 & 1005.712 & 944.571 & 1304.863 \\
0.012 & 753.236 & 1005.882 & 944.749 & 1305.073 \\
0.014 & 753.327 & 1006.077 & 944.939 & 1305.313 \\
0.016 & 753.425 & 1006.296 & 945.142 & 1305.583 \\
0.018 & 753.531 & 1006.538 & 945.361 & 1305.881 \\
0.020 & 753.644 & 1006.802 & 945.595 & 1306.207
\end{tabular}

Combining the above results, we set the ridge parameter $\lambda=0.008$. Repeating the above procedures, we get the ridge parameters for all of our dependent variables as in Table $\mathrm{C} 4$. 
Table C4: Ridge Parameters for all four regressions.

Dependent variables $\lambda$

Log of total risk $\mathrm{t}+1$

0.008

Log of total risk $t+3$

0.01

Log of idiosyncratic risk $t+1$

0.01

Log of idiosyncratic risk $t+3$

0.014 